\title{
The Metre as a Metric: Canada's COVID-19 Conversion Kerfuffle
}

\author{
Egan J. Chernoff ${ }^{1}$ (I)
}

Accepted: 29 September 2021 /Published online: 11 November 2021

(C) Ontario Institute for Studies in Education (OISE) 2021

\begin{abstract}
As a Canadian mathematics educator, I have a vested interest in Canadian mathematics education matters. After all, to me, Canadian mathematics education matters. Knowing this little factoid, imagine my horror when it recently dawned on me that, no matter where I looked during this COVID-19 pandemic, all I saw was flippant treatment towards the metric system. As I detail in this article, COVID19 social distancing signage, here in Canada, presents indifference towards the metric system. For shame, Canada. For shame. For the record, despite what nearly all the signs around us say at the moment, $2 \mathrm{~m}$ is not $6 \mathrm{ft}$. And, while I am at it, also for the record, $6 \mathrm{ft}$ is not $2 \mathrm{~m}$. Whether it is small business, big business or even the different levels of Canadian government (i.e., municipal, provincial or federal), it does not matter, the metric system is being poorly presented here at home during this global pandemic. The only good news, I am numb to it all now, which has helped me move on and start looking for other Canadian mathematics education matters. Stay tuned.
\end{abstract}

Résumé En tant qu'enseignant canadien des mathématiques, tout ce qui a trait à l'éducation des mathématiques au Canada m'intéresse activement. Après tout, l'enseignement des mathématiques au Canada compte selon moi. Sachant ceci, imaginez le sentiment d'horreur ressenti lorsque j'ai réalisé récemment que peu importe où je posais mes yeux durant cette pandémie de COVID-19, je ne faisais que constater qu'on traitait le système métrique que de façon désinvolte. Comme je l'explique dans cet article, la signalétique concernant la distanciation sociale requise en temps de COVID-19 ici au Canada se montre indifférente en regard du système métrique. Honte au Canada. Honte. Je tiens à rappeler que contrairement à ce que presque toute la signalisation qui se trouve autour de nous en ce moment prétend, deux mètres n'égalent pas six pieds. Et pendant que j'y suis, afin que ce soit clair, six pieds ne sont pas deux mètres. Que cela concerne les petites ou les grandes entreprises, ou encore les différents niveaux de gouvernance au Canada (c'est-à-dire les paliers municipal, provincial et fédéral), cela ne fait aucune différence, ici à la maison durant cette pandémie mondiale on représente le système métrique de façon

Egan J. Chernoff

egan.chernoff@usask.ca

1 Department of Curriculum Studies, College of Education, University of Saskatchewan, 28 Campus Drive, Saskatoon, SK S7N0X1, Canada 
maladroite. La seule bonne nouvelle c'est que je suis maintenant insensible à cette réalité, ce qui m'a permis de commencer à m'intéresser à d'autres questions liées à l'enseignement des mathématiques au Canada. Demeurez à l'écoute.

I remember it like it was yesterday, while flying from Paris to Germany, my seatmate, a very thin, polite, elderly, European female was profusely, and I mean profusely, apologizing for having mistakenly assumed I was "an American". Me, not having made too big a deal about it, I used the "mistake" as an opportunity to start a short, polite conversation, just before dawning my very American-businessperson-looking Bose noise cancelling headphones and taking a much-needed nap for the rest of the flight.

"Well, we do watch a lot of American television in Canada", I began, just before attempting to explain CanCon percentages (i.e., the Canadian Radio-television and Telecommunications Commission requirements that radio and TV broadcast/produce a particular percentage of Canadian content). Looking to not make her mistake again in the future, our conversation morphed into differences between Canadians and Americans. "Some people will even sew or glue a Canadian flag right onto their backpack to avoid such a mistake", I said, wanting to start off with an easy one. We discussed the classics: apologizing (read: saying Sorry), hockey, beer, maple syrup, poutine, one- and two-dollar coins and the Canadian tuxedo. Before we finished, not wanting to come across as a total Hoser (played to perfection by characters Bob and Doug McKenzie in the The Great White North), one who only talked about toques (or touques) and moose, I mentioned some big differences: government, gun culture, immigration, official languages, health care and, of course, the metric system.

\section{Distance Walking During COVID-19}

Thanks to COVID-19, life has changed a lot recently. During this pandemic, as documented in the news, different people took up different activities. Making sourdough bread was popular for a while, for example. Me, I took up long distance walking to help pass the time. I am not sure what it is about walking all those kilometres, maybe it is the pace, but it gets me reflecting.

One day, while walking along the Vedder River Rotary Trail in Chilliwack, British Columbia, I was, once again, thinking about my conversation with my Paris-to-Germany seatmate. I began to wonder if and how COVID-19 would have impacted our "big differences" discussion. Then, there it was: a sign. No, not some weird divine intervention; rather, an actual sign (see Fig. 1).

Fig. 1 The City of Chilliwack: This is $2 \mathrm{~m} / 6 \mathrm{ft}$

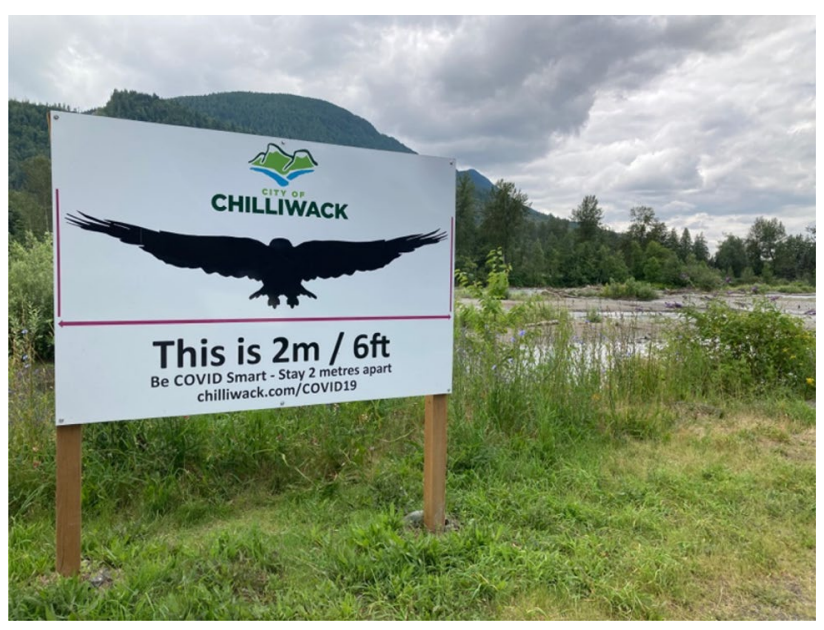


With a long way to go on my walk, my thoughts turned to the sign I had just passed. "The City of Chilliwack knows $2 \mathrm{~m}$ is not 6 feet, surely", was my first thought (perhaps question). Second, I was pleased that metres were put before feet on the sign. The full length visual, albeit a little dark, was a nice touch, but I could not get past not knowing whether the big bird measured $2 \mathrm{~m}, 6 \mathrm{ft}, 6.56168$ $\mathrm{ft}, 1.8288 \mathrm{~m}$, or some other distance. Having forgot, I started to wonder what grade they start teaching metric conversions in British Columbia and Saskatchewan. On and on, I kept thinking about the metric system as presented on this sign. As my walk was finishing, having taken a photo on my phone, I made note that the phrase on the sign, that is, "Stay $2 \mathrm{~m}$ apart" was in metric, as opposed to, for example, "Stay 6 feet apart". An interesting sign: some good stuff, some bad stuff and some stuff still left for me to investigate. If I am being honest, my worries for the metric system began as I got in the car after my walk.

At home on the computer, I did a quick Internet search concerning the " " symbol that was on the sign. Sure, I knew that the (forward) slash represented the division symbol for calculators and programmers, but I had forgotten many of the other meanings. Turns out, the slash: indicates a switch in command line syntax; is used to indicate "or"; form abbreviations; denotes dates; separates lines of prose; indicates connecting and conflicting relationships; and more. Late at night just staring at the ceiling Queen's Gambit style, no matter how I used the "/” symbol, I came to a simple conclusion: No matter how I looked at that sign, it was disappointing the metric system, definitely.

\section{Sign, Sign, Everywhere a Sign}

"Because, as Canadians, we are supposed to take pride in, not butcher, the metric system", I said to my wife over coffee the next morning. "It is damaging the metric system"?! she replied. "Yes", I continued, before going into a long diatribe that included: the majesty of the metric system; rounding errors; rounding versus truncating; truncating errors; metric to imperial conversions; issues with intuition; the Indiana Pi Bill; learning by osmosis; and, on and on and on. "It is just one measly sign, and I think, as you always do, you are making too big a deal of all this", was how my wife ended our morning coffee conversation. She did not know it at the time, but things were not ending; oh no, they were just getting started. I was now on the hunt, the hunt for signs.

With apologies to the Five Man Electrical Band, COVID-19 social distancing signage is everywhere; and, for quite some time now, whenever possible, I have been taking pictures of said signage. I will admit, I have had to explain myself on more than one occasion when a person asks why I am taking a picture of "the wall", which, typically, goes something like this:

Actually, it is not a picture of the wall, it is a picture of the social distancing signage hanging on the wall. You see, as a Canadian mathematics educator, one with a vested interested in Canadian mathematics education matters, I am worried that, Canadians, especially young Canadians, are being presented a warped notion of the metric system. We definitely cannot have Canadians thinking that 2 metres is 6 feet or 6 feet is 2 metres. My biggest fear, I must admit, is people walking around, constantly witnessing poor presentation of the metric system, and not even caring.

Yes, the above presented response is fictitious. More accurately put, it is my dream response. In reality, I have never even gotten close to giving my dream response. The people that I have spoken with, usually concerned that I am trying to document them not staying $2 \mathrm{~m}$ apart from other people, typically tune out after I mention something about, "It is an informal, yet very important investigation into the metric system". Even worse, those times that I have engaged with people who have asked 
me about my off-beat photography. Sure, the "I just do not see the big deal if people think $2 \mathrm{~m}$ is 6 feet", response was hard for me to hear, but not as hard to hear as the response from the backward ball-capped, adult male that said to me, unabashedly by the way, "No, Dude, I am pretty sure $2 \mathrm{~m}$ is 6 feet. I saw a sign about it somewhere one day" (see Fig. 2).

As you might expect, the signage is very, very diverse. Signs with extremely high production value are found in Big Business stores (e.g., Home Depot, Winners and the like) and from various levels of Canadian government (e.g., federal, provincial and municipal). These signs are made of hearty materials and portray distancing information with bold and colourful fonts and symbols. Lower production value signage, for example, those signs printed off an inexpensive, black and white, cartridge printer, and hung with a small piece of scotch tape, adorn the front door and walls of many of my favourite hole-in-the-wall restaurants and small business. These are the three categories for the social distancing signage critique that follows: Small Business Signage, Government Signage and Big Business Signage. As I will now present, amongst the diverse COVID-19 social distancing signs that exists in (certain parts of) Canada, I contend there is one common thread: a casual disregard/indifference for the metric system. Let us first look at Small Business.

\section{Small Business Signage}

Before I started taking pictures of small business signage, I made a few notes to myself, which read, "Wild, Wild West" and "Feet". Now, before you get ahead of yourself, translated, my notes to myself meant, one, that I was expecting anything and everything when it came to small business signage and, two, an emphasis on the imperial system of measurement, in general, and, in particular, six feet. I am sorry to say my notes were soothsayish.

After taking several photos of small business social distancing signage, three of which are presented in Figs. 2, 3 and 4, I can confirm that anything and everything does go out there when it comes to signage. There are a number of stores and restaurants, more than I would like to admit, declaring that 6 $\mathrm{ft}$ equals $2 \mathrm{~m}$ or $2 \mathrm{~m}$ equals $6 \mathrm{ft}$, which is not good. While some stores are explicit in their declarative "conversions" (see Figs. 2 and 3), other stores (see Fig. 4) are more subtle. Whether explicit or implicit, all I see is an indifference to the metric system, which I cannot unsee at this point.

As for the emphasis on the imperial system of measurement, also in my notes, that is also there if you look for it. Unlike government signage, which will see in the next section, I have yet to find

Fig. 2 Small business signage: 2 METERS $=6$ FEET

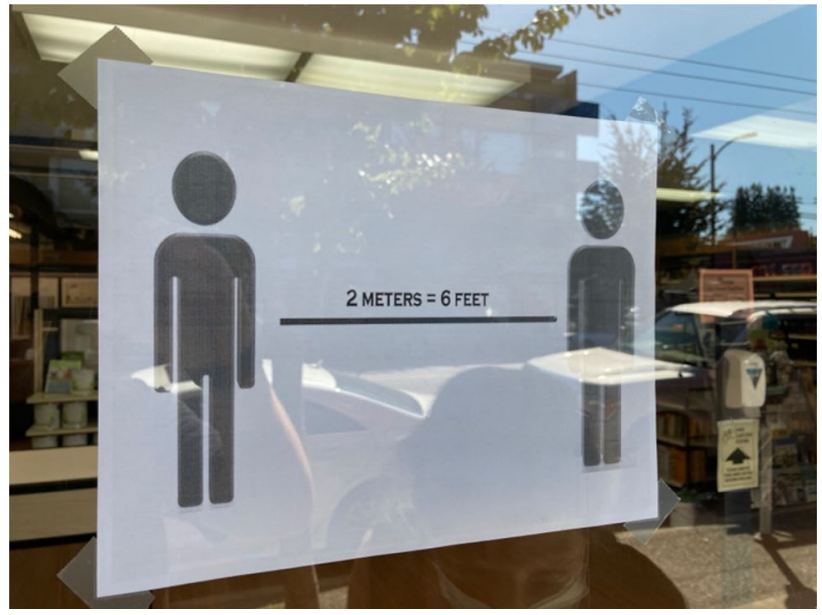


Fig. 3 Local produce store (Vancouver): $6 \mathrm{ft}=2 \mathrm{~m}$

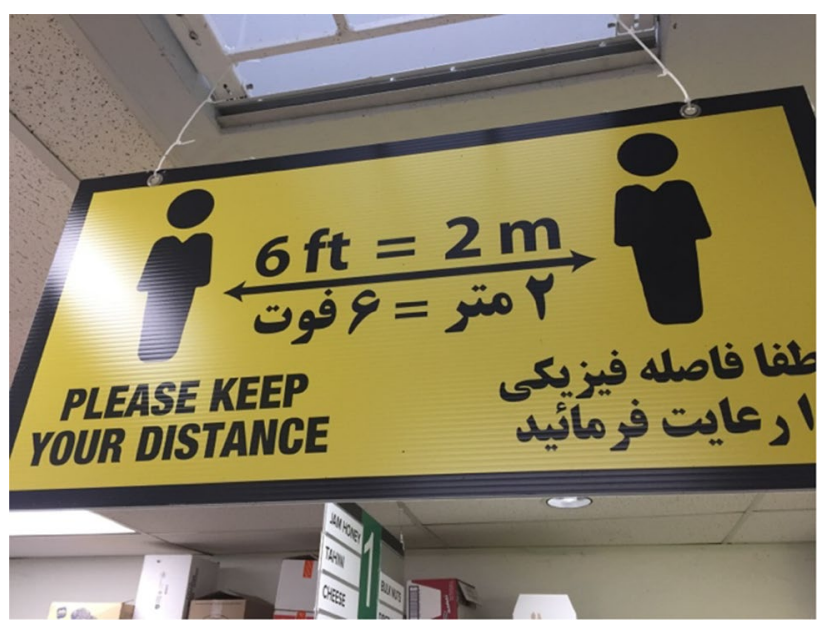

hard-and-fast, imperial-versus-metric rules when it comes to small business signage. Some signs, yes, ask you to stay $2 \mathrm{~m}$ apart; however, there are many more signs out there asking you, simply, to stay 6 $\mathrm{ft}$ apart, which seems a bit too American for my liking. Whether $2 \mathrm{~m}$ or $6 \mathrm{ft}$, there are, in the end, not that many signs with only one system or the other; rather, most small business signage references both systems of measurement.

Fig. 4 Medical laboratory (Vancouver): 2M। 6ft

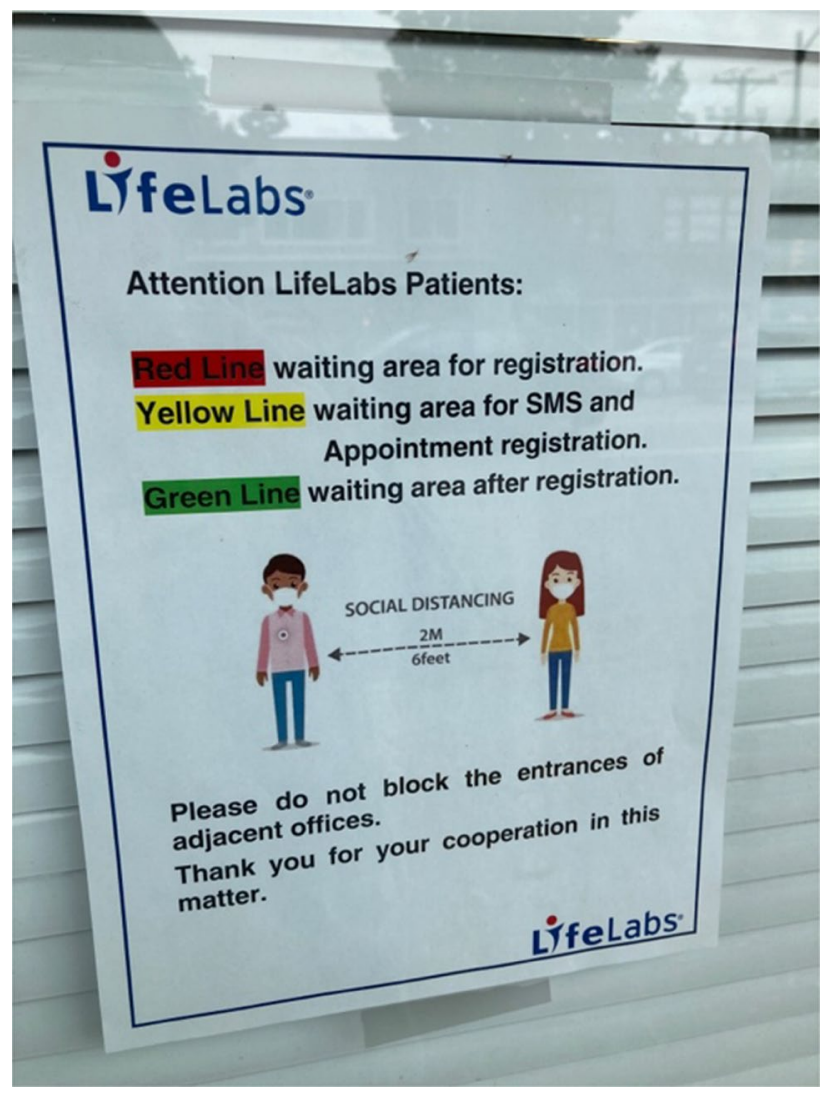


Fig. 5 Granville Island: 2 metres $=6$ feet $=2$ arms length

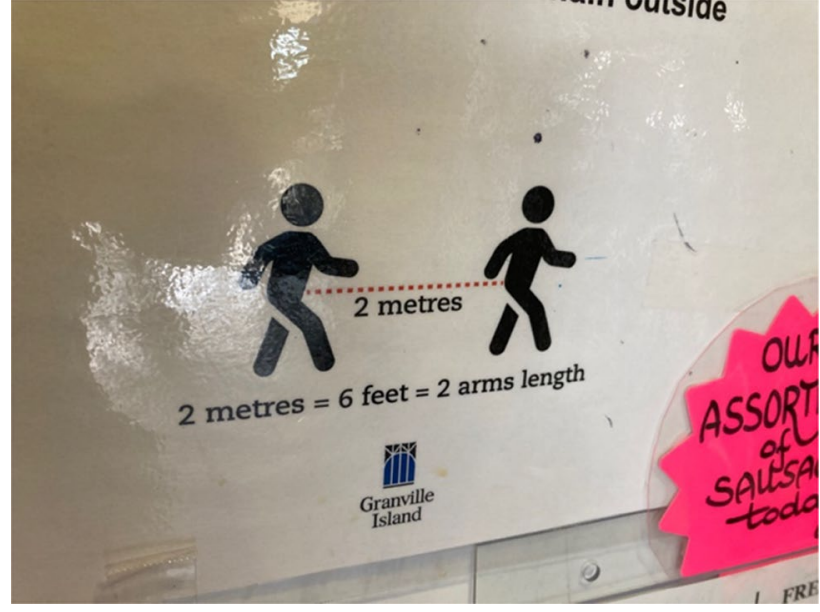

I should, here, admit my perspective (read: bias) when it comes to looking at small business signage and the order of the presentation of the metric and imperial systems. As a Canadian who (primarily) reads the English language from left to right, an ideal sign, for me, starts with the metric system, used here in Canada, followed by an appropriate conversion to the imperial system of measurement. All I was looking for, for example, was a sign that said, "Please maintain social distancing (while visiting our small business): $2 \mathrm{~m}$ or approximately 6 and a half feet". A bridge too far, I guess.

While continually looking for my version of an ideal small business sign (to reiterate, metric before imperial along with an appropriate conversion), I stumbled upon something else: a new non-standard metric was added to the mix. While entering Granville Island, BC, I encountered a sign that was still dismissive to the metric system, unfortunately (shown in Figs. 5 and 6). It was nice, however, that Granville Island presented metres before feet, but declaring they are equal somewhat rendered any order moot, in my opinion. A new wrinkle, though, was the addition of a new system of measurement based on somebody's human body: 2 arms length. All of a sudden, upon seeing this sign, I had a whole new worry to deal with. I had been concerned and focused on the notion that people needed to know that $2 \mathrm{~m}$ was not $6 \mathrm{ft}$ and $6 \mathrm{ft}$ was not $2 \mathrm{~m}$, but what the sign in front of me was suggesting was that people might need an aid in discerning what $6 \mathrm{ft}$ looks like?! As I stood in line at Oyama Sausage Co., I stared at the concrete floor asking myself if I could actually discern a distance of $2 \mathrm{~m}$. Unable to "see" a pure $2 \mathrm{~m}$ in front of me, I began to worry about the metre as a metric. My worries would not be alleviated when I started shooting government signage.

Fig. 6 Granville Island: 2 metres $=6$ feet $=2$ arms length

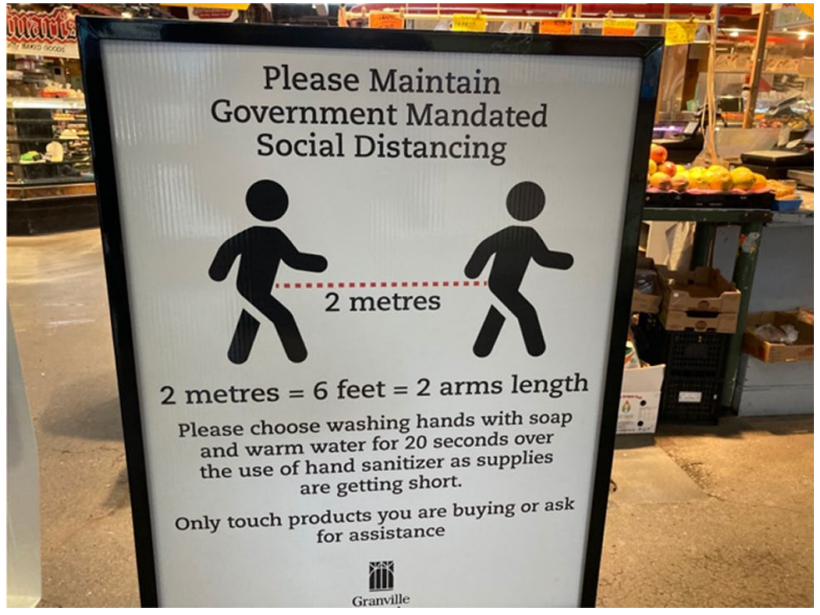




\section{Government Signage}

As was the case with small business, I made a few notes after seeing the Vedder River Rotary Trail sign, but before taking pictures of other government signage. My notes read, "Up the ladder means more metric". Translated, my note to myself meant that I expected municipal signage to have a mixture of metric and imperial, whereas federal signage would be purely metric. Provincial signage then, which fell between municipal and federal was to also be a mixture but to have less of a focus on the imperial system of measurement. Although not explicit in the note, I was also expecting metric to appear first and no signs to only have the imperial system. Other expectations, not found in my note, were less butchering of the metric conversions by various levels of Canadian government. Finally, having seen the big bird on the Chilliwack sign, I wondered if other, non-standard metrics might enter the mix.

Taking a break from walking 1 day, we headed to Harrison Hot Springs, where we were met with new steep parking prices and a smiling Sasquatch (see Fig. 7). Akin to the signage in Chilliwack (see Figs. 1 and 8), I witnessed presentation of the metric system before the imperial system (if read left to right), use of the "/" symbol to "convert" metres to feet, and the hands of a Sasquatch that are $2 \mathrm{~m}$, $6 \mathrm{ft}, 6.56168 \mathrm{ft}, 1.8288 \mathrm{~m}$, or some other distance apart. Attempting to get a better sense of the actual distance, I started pacing it off before my wife said, "What are you doing? There are people around here". To which I replied, "Did you notice this sign says 'meters' and not 'metres'? What do you think that is about"? Given the signage that I had seen thus far, I began to recalibrate my metric expectations.

As it turns out, as you will see in Figs. 9, 10, 11, 12, 13 and 14, it does not matter if you are in Saskatoon, Saskatchewan, Banff, Alberta, or Vancouver, British Columbia, there appears to be a default presentation for government-related social distancing signage.

Government signage, always it appears, will present the metric system before the imperial system. This is Canada after all. In addition, the majority of signage simply presents two distances, one distance of $2 \mathrm{~m}$ and another distance of $6 \mathrm{ft}$ and leaves the rest up to us. I should point out, here, that the World Health Organization's (WHO's) physical distancing guidelines are in metric and recommend staying $1 \mathrm{~m}$ apart from each other. Thus, should an individual choose the imperial system to guide their social distancing then, no, they are not staying $2 \mathrm{~m}$ apart, but, yes, they are well over the WHO guidelines. But I digress, let us get back to the signs and my acquiescing.

Fig. 7 Harrison Hot Springs: THIS IS 2 METERS / 6 FEET

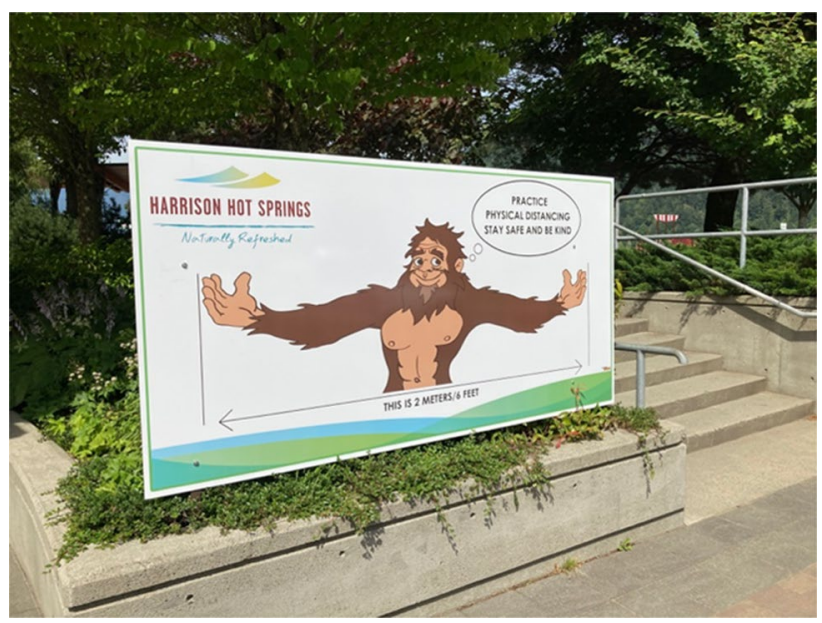


Fig. 8 City of Chilliwack:

This is $2 \mathrm{~m} / 6 \mathrm{ft}$

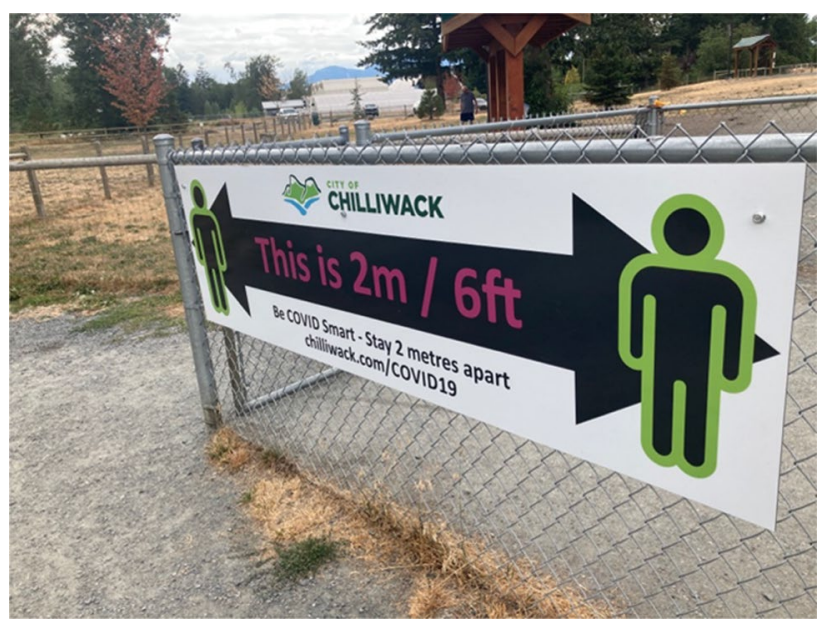

It was not going to be easy, but it was time for me to get over the butchered presentation of $2 \mathrm{~m}$ or $6 \mathrm{ft}$ that stared back at me everywhere I looked. Rather, it was time to start looking for little victories. Knowing that the signage I was encountering was not going to be perfect, in my eyes, I started to look and see how close to the sun I could fly. It would not take long to see some nice signage that I, as a Canadian mathematics educator, would be comfortable discussing or defending should the opportunity, for some reason, ever arise.

Fig. 9 City of Saskatoon: 2 $\mathrm{m} \mid 6 \mathrm{ft}$

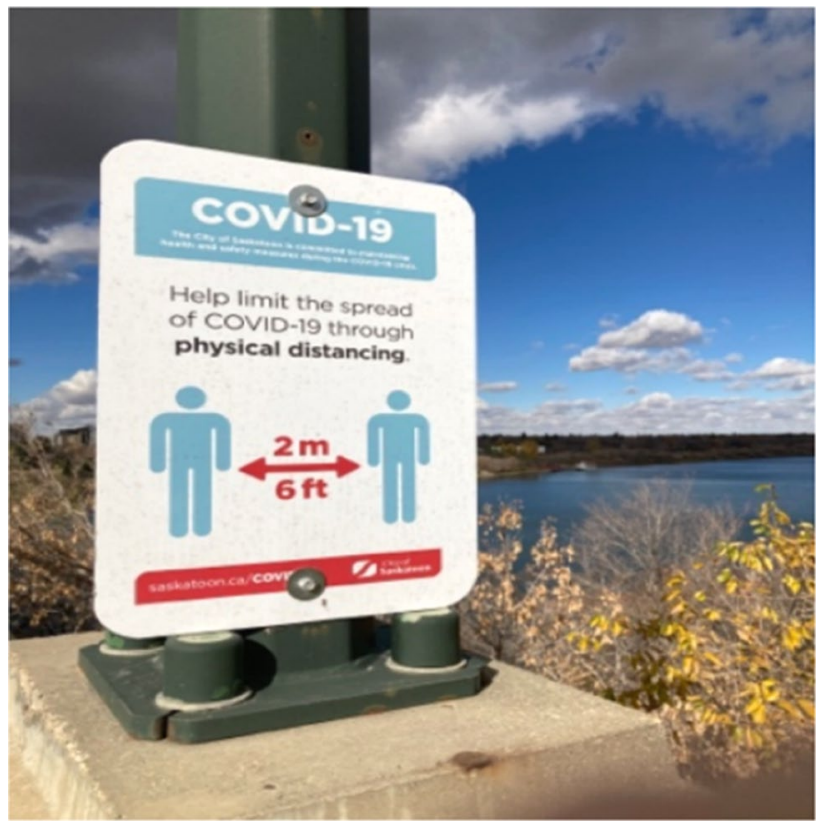


Fig. 10 Saskatoon Transit: Please Stay 2 Metres (6ft) Apart

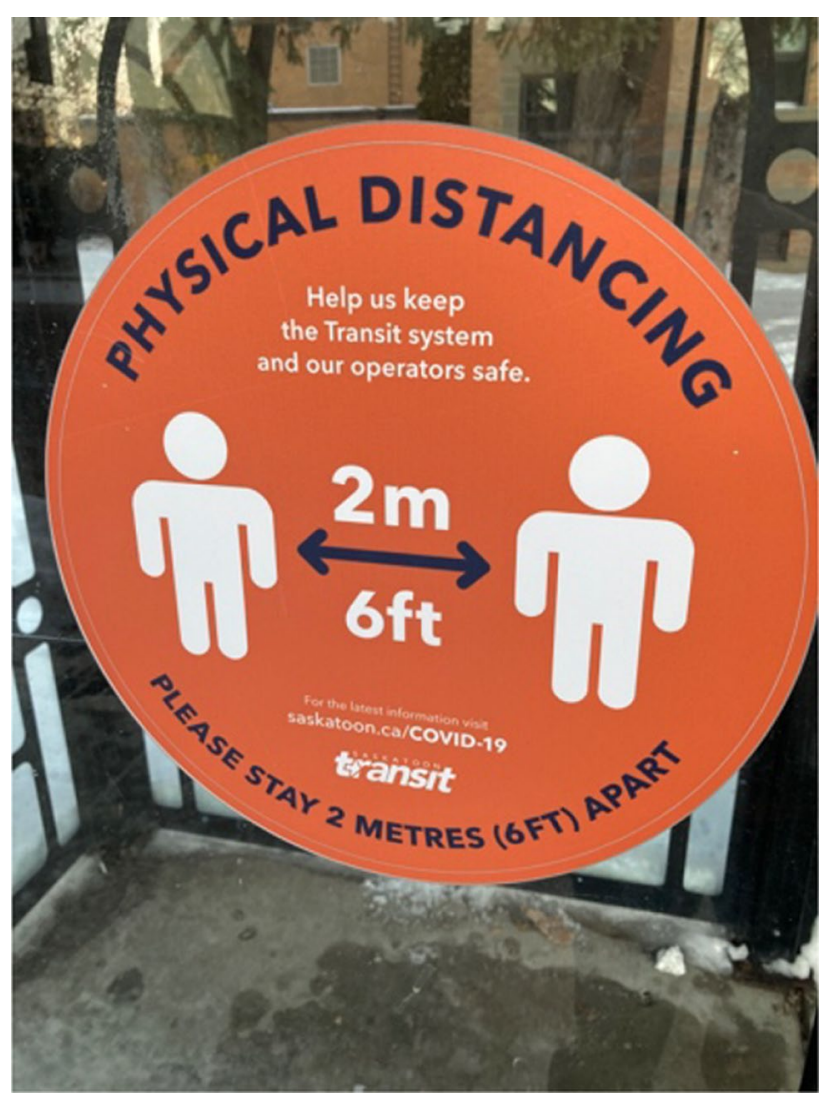

Walking in Vancouver parks always puts a smile on my face, especially in the rain. Thanks to the Vancouver Board of Parks and Recreation, who are responsible for the signs that are seen in Figs. 11 and 12, my smile was extended even further the day I encountered and captured their signs that

Fig. 11 Vancouver Board of Parks and Recreations: $2 \mathrm{M}$

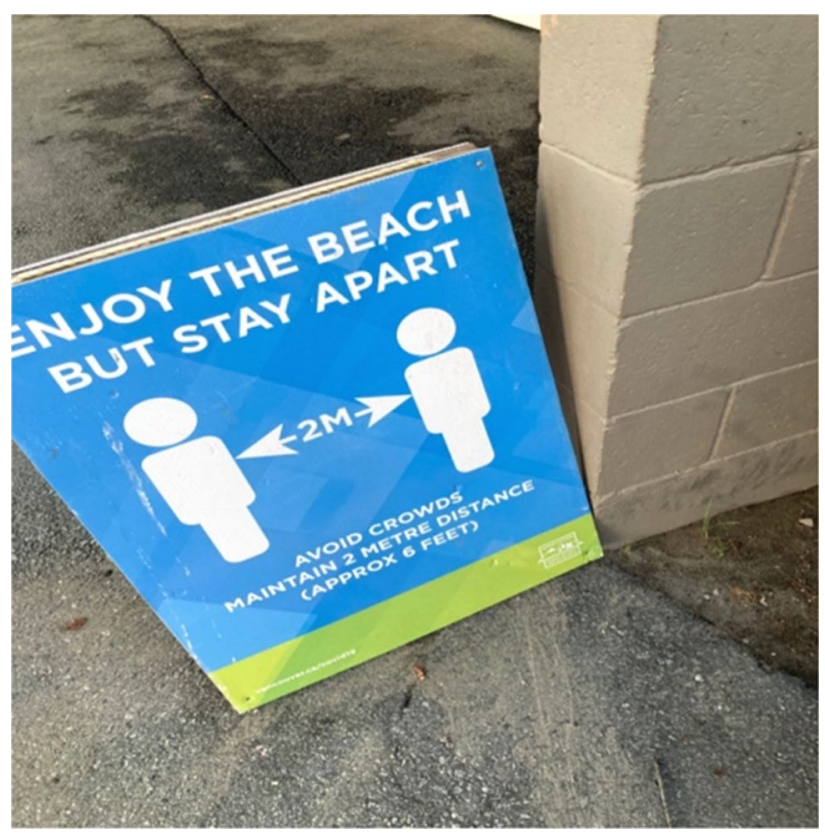


Fig. 12 Vancouver Board of Parks and Recreations: $2 \mathrm{M}$

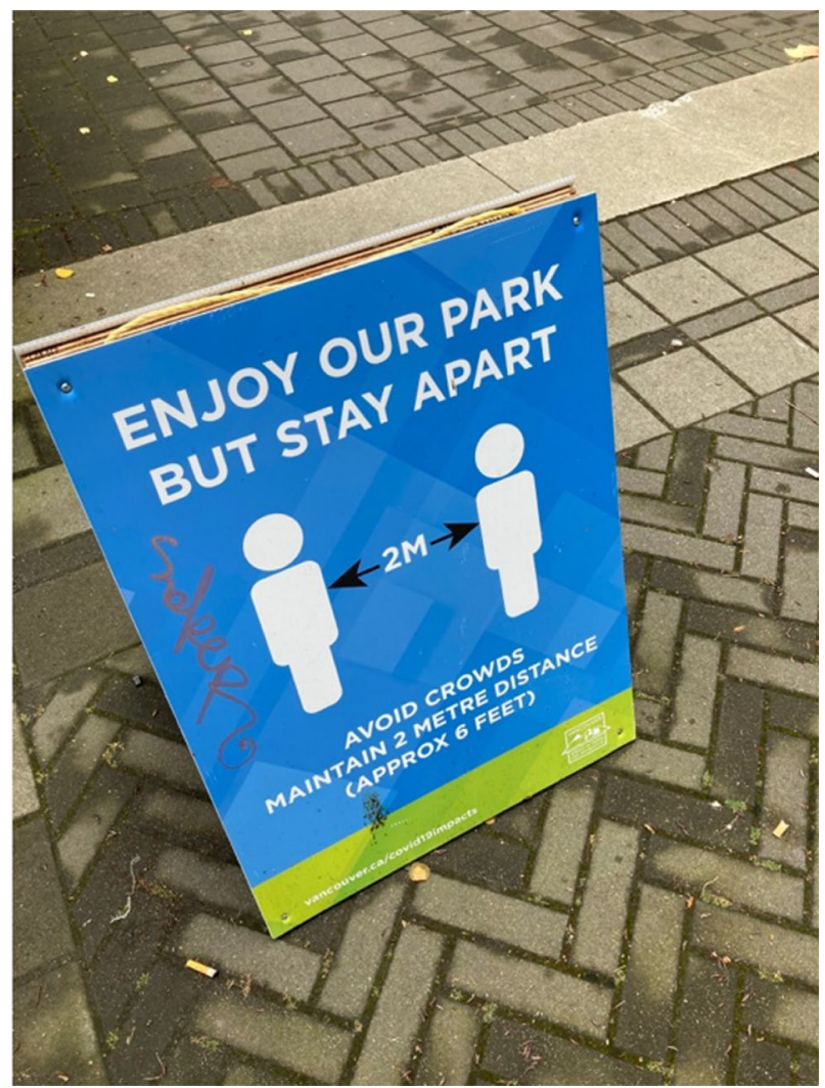

asked us, simply, to stay " $2 \mathrm{M}$ " apart. So simple, yet it had everything I was looking for in COVID19 distancing signage: presentation of a metric metric, that is, $2 \mathrm{~m}$. Making the sign even better, in my eyes, should you need further clarification, an excellent elaboration: "MAINTAIN 2 METRES DISTANCE (APPROX 6 FEET)". Not $6 \mathrm{ft}$, approximately $6 \mathrm{ft}$ ! Well done, Vancouver Board of Parks and Recreation, well done.

With my faith a bit restored, I soon found other instances of the new standard set by the Parks and Recreation Board in Vancouver. Getting ready for a walk through Mundy Park in Coquitlam, BC, I

Fig. 13 City of Coquitlam:

2 metres apar

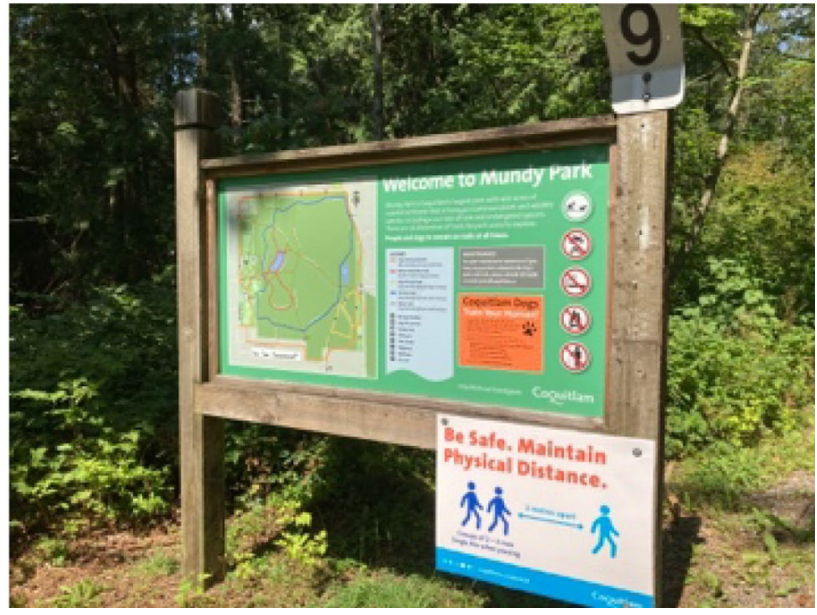


Fig. 14 City of Abbotsford: at least 2 metres ( 6 feet)

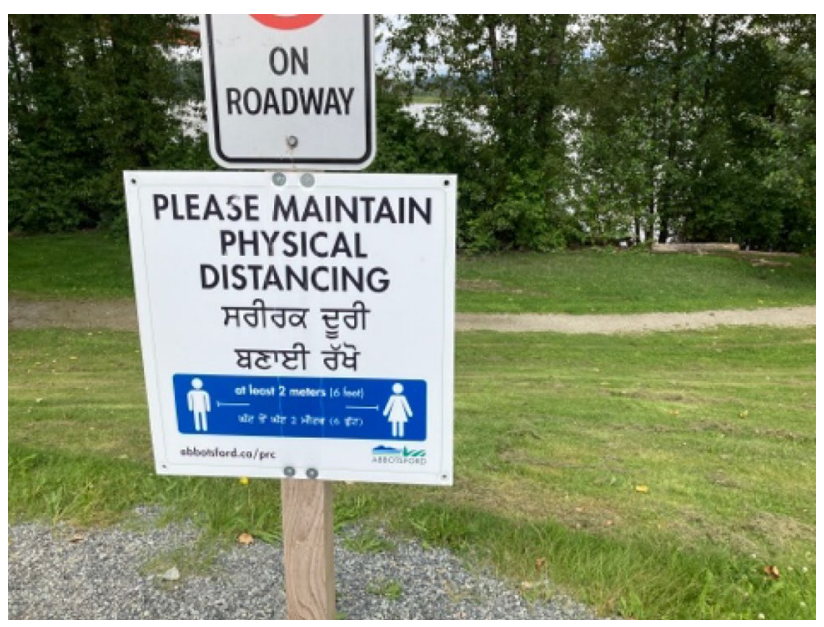

snapped a sign (see Fig. 13) that said, simply, "2 m apart". Thank you, Coquitlam. Your trust in me knowing what $2 \mathrm{~m}$ looks like when walking through one of your parks was much appreciated. On that note, a quick shout out to the City of Abbotsford (see Fig. 14) whose sign we encountered while walking on the Sumas River Dyke Trail. While I am, clearly, not a fan of your presentation of " $2 \mathrm{~m}$ (6 feet)", the former math teacher in me appreciates the attempt to integrate the phrase "at least" into your sign, Sumas. "At least" is something that is not found in a lot of social distancing signage, Abbotsford, and, instead of getting hung up on how "at least" could and should apply to two numbers that are not equal to each other, you too helped restore my faith in Canadian COVID-19 distancing signage.

Our way back from checking in on our parents in British Columbia necessitates a stop in Alberta. Whether we take the northern route and drive through Jasper or the southern route and drive through Banff, on our way back to Saskatoon, we have an agreement to not look at our phones as we drive through the Rocky Mountains. No exceptions. Normally, I love this rule. Whether I am in the driver's seat or the passenger's seat, I spend time just looking up at the amazing scenery. This time, however, while in the passenger's seat, I caught myself staring at the side of the road looking for $2 \mathrm{~m}$, to no avail. Stopped at the park entrance for Banff, still looking at the side of the road, I began to worry. If I was having difficulty seeing a pure $2 \mathrm{~m}$, then there is no way I would be able to differentiate between 1.8288 and $2 \mathrm{~m}$ or $6 \mathrm{ft}$ and $6.56168 \mathrm{ft}$. Then, I remembered the sign at Granville Island, the sign with the humanbased metric of 2 arms length. With the metre as a metric failing me at this point, I wondered what else was being used to frame $2 \mathrm{~m}$, if not $6 \mathrm{ft}$ or 2 arms length, that could help.

It takes us about $10 \mathrm{~h}$ to get from Vancouver to Banff, which means that it is time to stretch our legs when we get there. Too late in the day to get in a hike, we decided to walk through town, which I am glad we did. With everybody around me taking the famous Banff Avenue photo, there I was taking photos of the social distancing signage in the middle of the now closed off avenue. Like Granville Island, the Banff signage utilized alternative metrics to help people with their social distancing efforts, albeit animal- and not human-based.

Having difficulty, myself, seeing $2 \mathrm{~m}$, I was perhaps more receptive to the alternative framing of $2 \mathrm{~m}$ or $6 \mathrm{ft}$. (Ugh, now even I am saying it.) However, I was not a fan of the alternatives that were being presented to the citizens and tourists of Banff, Alberta (see Fig. 15). Having hiked in Banff for a number of years, I have only come across an elk on the trail (the actual trail) once, which was huge. In fact, I have encountered way more elk while camping at Tunnel Mountain, especially during rutting season. The thing is, I have never really paid attention to how "far apart" their antlers are; rather, we are always interested in how "big" they are. Like I said, though, I get it, using elk is on brand for Banff. 
Fig. 15 Banff, AB: That's about the width of an elk's antlers

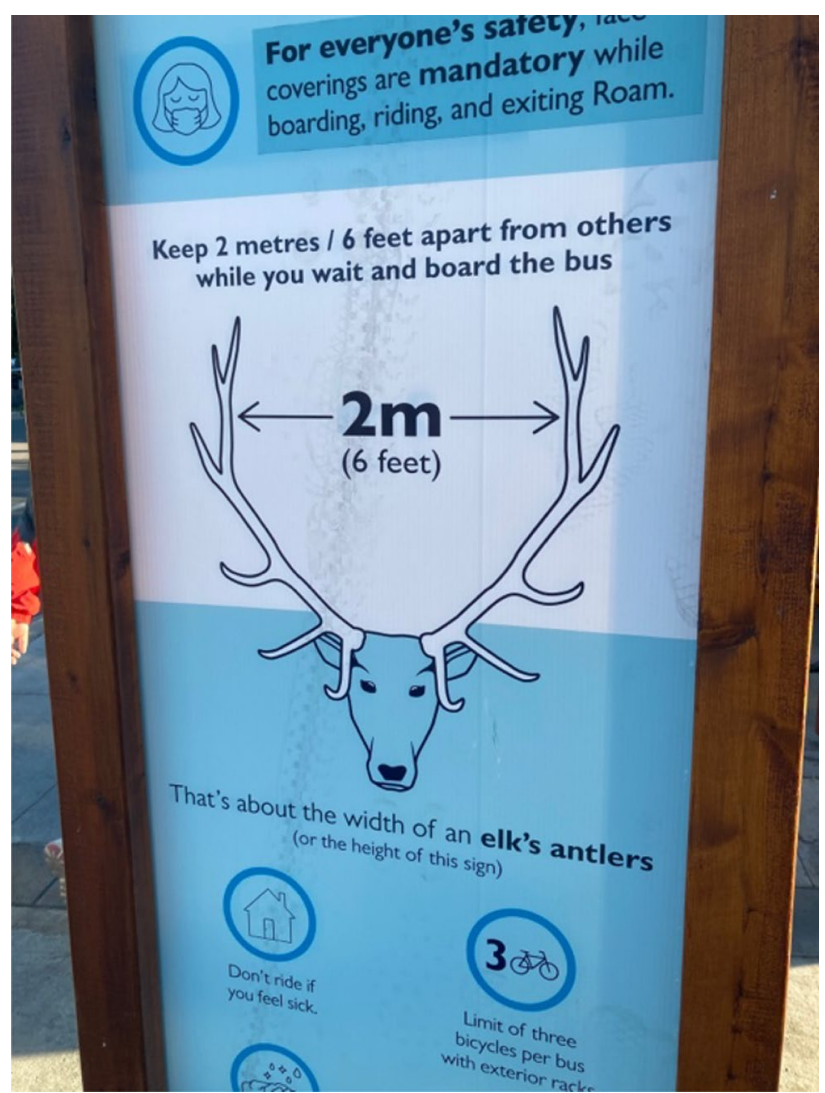

As for the other metrics (see Fig. 16), the hockey stick and the hiking pole, those really started to bother me while walking around town. "What is the matter now"? my wife asked. "As a six foot tall person, do you think the hockey stick I use goes from the floor to the top of my head? Have you ever, I mean ever, seen a hockey player with a stick that is as tall as they are. I will answer that, no". The same, I should mention, goes for hiking poles. A quick Internet search and you will agree, a $2 \mathrm{~m}$ long hiking pole is for a very, very tall person. "Look at the sign", my wife said, "neither the pole or the

Fig. 16 Banff, AB: Hockey sticks and hiking poles

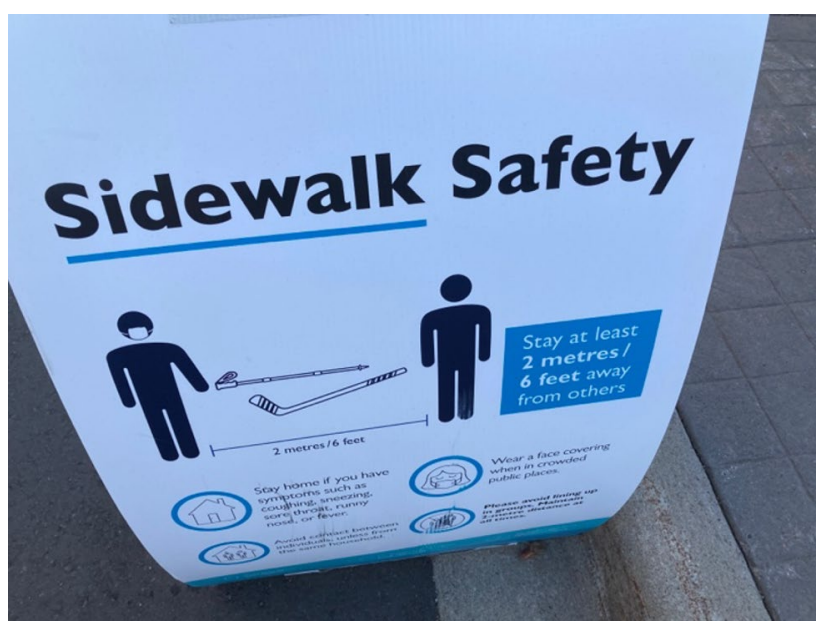


hockey stick runs the entire length of the line in the diagram". To which I replied, "Yeah, ok, but the line that you are referring to exists as both $2 \mathrm{~m}$ and 6 feet at the same time". Alone on my own for a while, my wife went off to check a few things on her own, I began to wonder whether the stick or the pole is supposed to represent $1.8288 \mathrm{~m}$, before quickly dismissing that notion. Still thinking about the metric system, I had one more photo to take while in Banff.

For those of you that know Banff Avenue, you know that the postal office is just before the bridge. That is exactly where I was headed. I wanted a photo of what the postal office was asking people to do when it came to social distancing. I wondered if they would be using a bunch of envelopes to show a distance of $2 \mathrm{~m}$ like was seen in the Banff signage. Nope, the sign on the post office, while rather simple, had all of the issues that I had had with all the other signs seen in small business and from other levels of government (see Fig. 17).

Sure, I expected to see the metric system presented before the imperial system. What I did not expect to see, though, was the $2 \mathrm{~m}$ or $6 \mathrm{ft}$. I began to wonder if the Parks and Recreation Board in Vancouver was a bit of an anomaly and who or why they decided to put "approx 6 feet". With all the photos that I could find, it was time to turn in and turn attention to the long drive from Banff to Saskatoon the next day. Scrolling through the photos on my phone in the car that next day, I stumbled onto some photos that my wife had taken, but kept to herself.

\section{Big Business Signage}

I am not saying it is right, but I am saying that big business is definitely influencing the world we live in, especially lately. Arguments over Costco, Walmart and Amazon killing small businesses, for example, abound. Stories of people getting their news from Facebook as opposed to the Canadian Broadcasting Corporation would be another example. In line with this reasoning, I made sure to snap COVID-19 signage as I entered and exited certain Big Businesses.

The two notes that I had made to myself, that is, "Imperial, imperial and imperial" and "High production value", were immediately witnessed the moment I stepped into Winners one day (looking for a deal on running socks, which I found). As seen in Figs. 18 and 19, unlike government signage, the imperial system is presented before the metric system in this particular big business. "Six feet", then, for the customer, is alternatively framed and presented as $2 \mathrm{~m}$, in one instance, and as " 2 cart lengths apart".

Fig. 17 Banff Post Office, AB: $2 \mathrm{~m} \mid 6 \mathrm{ft} . / \mathrm{pi}$

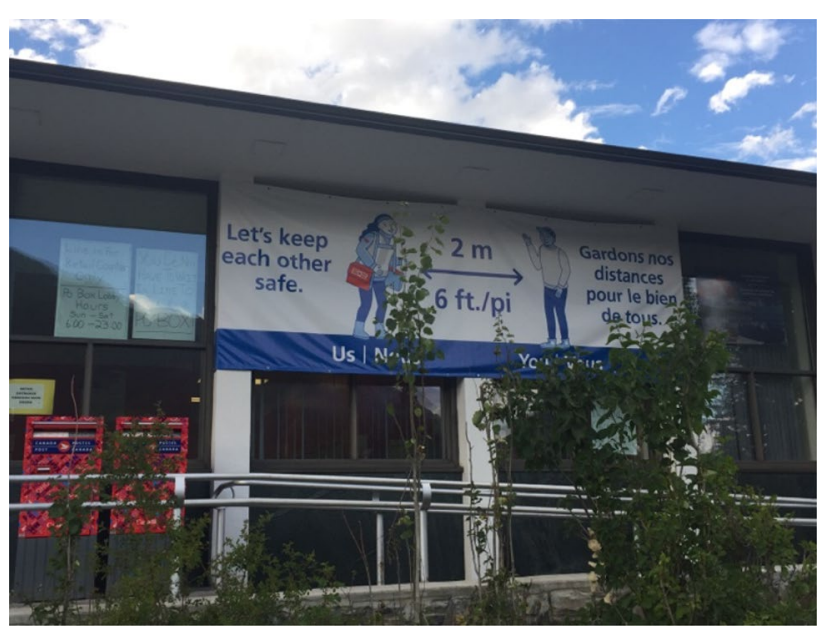


Fig. 18 Winners: $6 \mathrm{ft}$ or 2 cart lengths apart

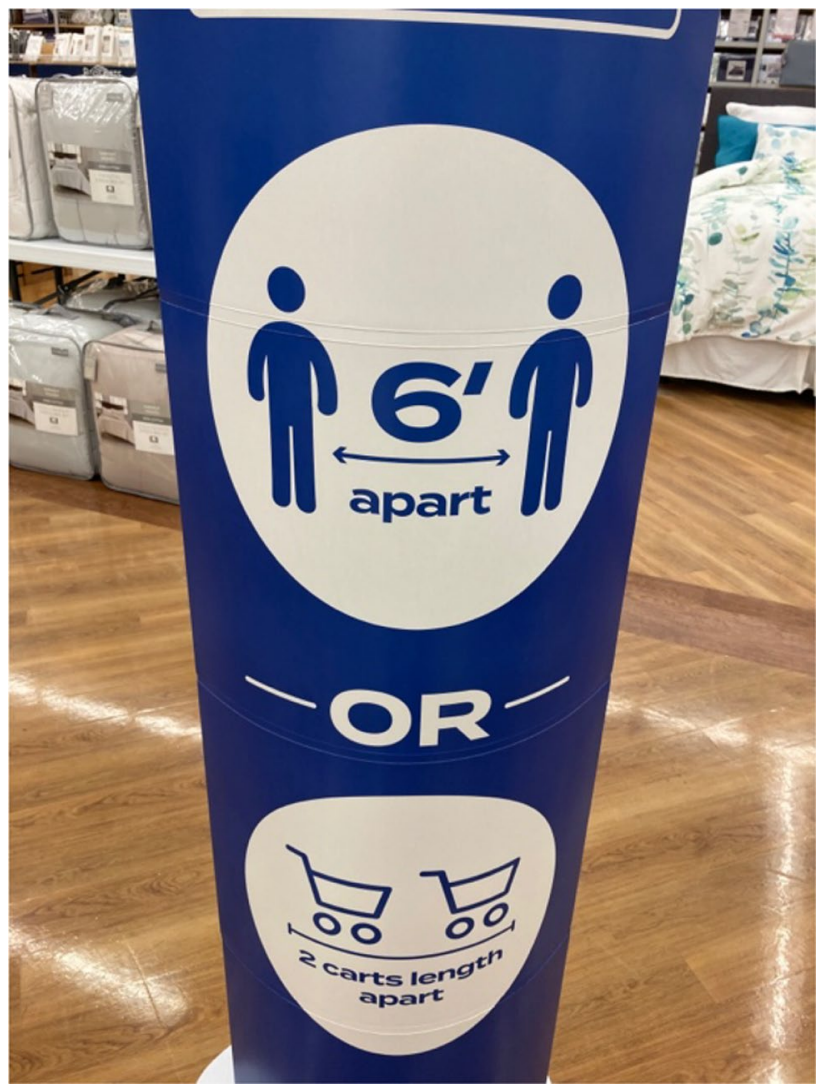

Not carrying around a tape measure, I did manage to pace off a cart, albeit discretely. I found two things. First, I found myself thinking that two cart lengths, actually, was not a bad alternative presentation of $6 \mathrm{ft}$. The second thing I noticed, I was getting soft. Here I was, railing against $2 \mathrm{~m}$ is $6 \mathrm{ft}$ and now $6 \mathrm{ft}$ is $2 \mathrm{~m}$, which it is not, and now I was acquiescing over presentation of the imperial system followed by cart length and completely without a sniff of the metric system. Gathering myself quickly, thoughts turned to whether or not the store had "brought up" some signage from the USA and just plopped it down in the middle of their Canadian stores. I could definitely see this being the case in Fig. 18. I could not

Fig. 19 Winners: $6 \mathrm{ft} / 2 \mathrm{~m}$

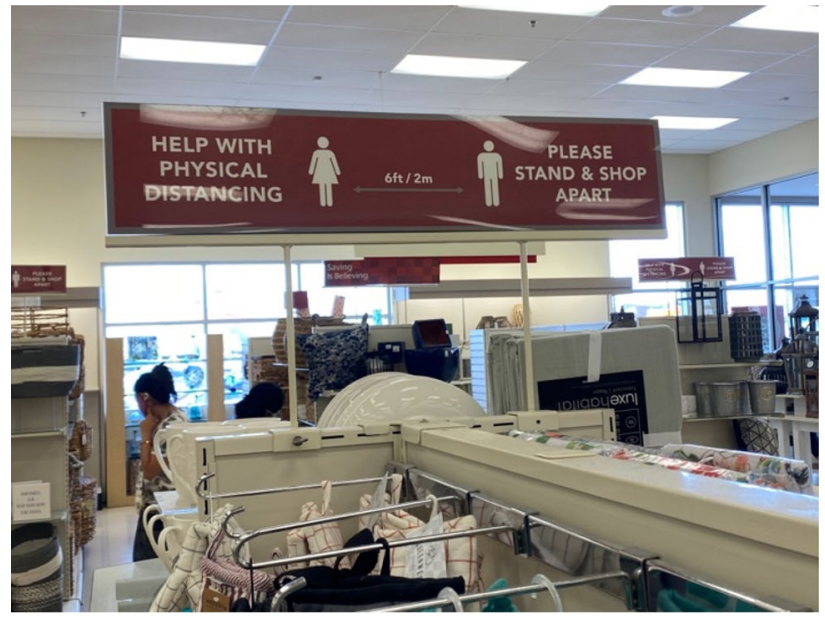


imagine the sign featured in Fig. 19 hanging in a Winners situated in the USA. If Rick Mercer and his show, Talking to Americans, has taught me anything, the " $2 \mathrm{~m}$ " part would cause confusion more than anything. Scanning at a wall of socks, I imagined being a fly on the wall at a Winner's board meeting. A discussion of "saving money" by using some of the signs already made for American stores, and only having to print a few with the metric system, would be followed by a suggestion from a young go-getter, one looking to climb in the company, telling everyone else to make sure the ones with the " $\mathrm{m}$ " on it are, at the very least, hung prominently for the Canadian stores. With my new socks in hand I made my way over to Home Depot, which, based on some Big Business decision made somewhere, is always surprisingly close, geographically speaking, to Winners.

Putting on my mask while walking into Home Depot, my "two sign” theory for Big Business garnered a bit more support. Prominently hanging in the entrance way (Fig. 20), a shiny new sign with, get this, the metric system presented before the imperial system, which had my hopes up. Sure, Home Depot, just like everybody else, was not worried that $2 \mathrm{~m}$ is not $6 \mathrm{ft}$. Nevertheless, at least one big business was leading with the metric system. Then, as I made my way deeper into the bowels of Home Depot, the "other" signs appeared.

Fig. 20 Home Depot: 2

Metres I 6 feet

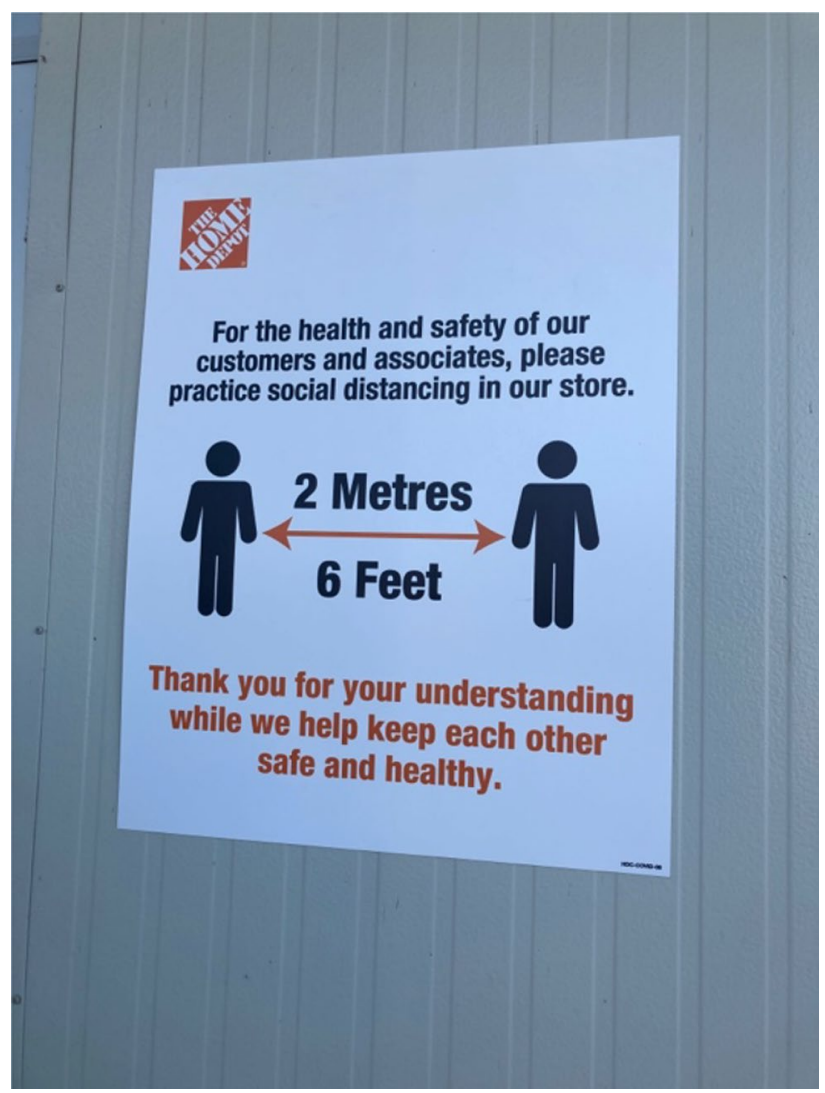


Fig. 21 Home Depot: 6 feet 6 Buckets

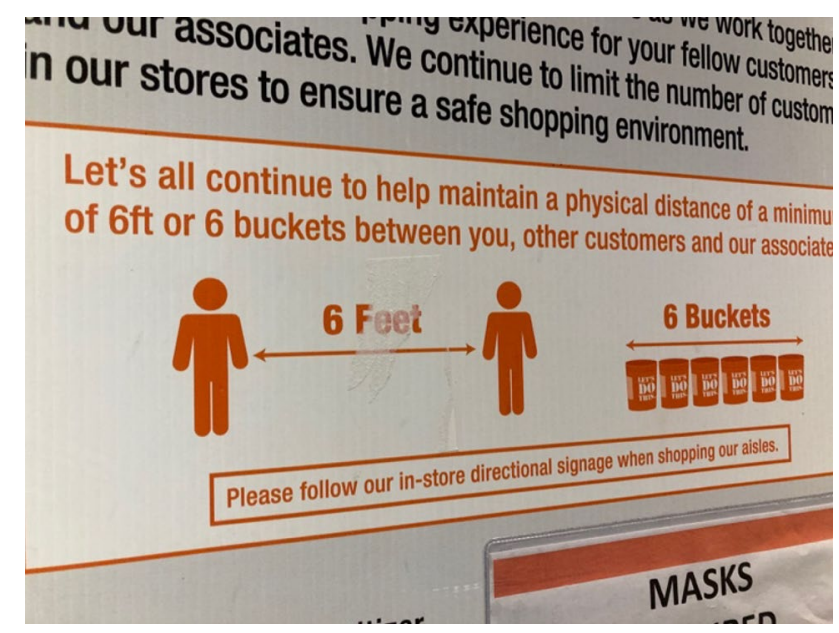

A number of signs, all the exact same as the one shown in Fig. 21, appear once you are inside the Home Depot. As you can see, and as was the case with the Winners sign in Fig. 18, no metric system. The imperial system is presented, followed by an alternative framing to help the customer relate to something in the store. No cart this time. Rather, the famous orange Home Depot bucket was helping customers relate to distancing requests. For those of you wondering, yes, I immediately put my home improvement purchases on hold, temporarily, in order to find the aisle with the orange buckets. Armed with a tape measure that I found in a different aisle, I was determined to establish the diameter of the orange Home Depot bucket. Like Winners, not bad.

Way out on the edge of town, where Winners and Home Depot are located in many Canadian cities, it just made sense to stop at Costco and see if I could find further support for my two sign theory. Figures 22 and 23 show pictures of the signage found both in front of house (Fig. 23) and the very back of the house, the road salt section (Fig. 22) of Costco. No two signs here at Costco it seemed.

Costco, as a premise, with apologies to No Frills, is all about no frills. Plopping pallets on a cement floored covered with a "big box", I am told, leads to savings. How else do you get 31 of mayonnaise for $\$ 7.99$, I ask you?! This approach to the store, I found, was also witnessed in their distancing signage. Somewhat suspect production value for such a major, major company, coupled with the use of scotch tape to hang signs off of the tills, reminded me of small business signage. However,

Fig. 22 Costco: $2 \mathrm{~m}(6.5 \mathrm{ft})$

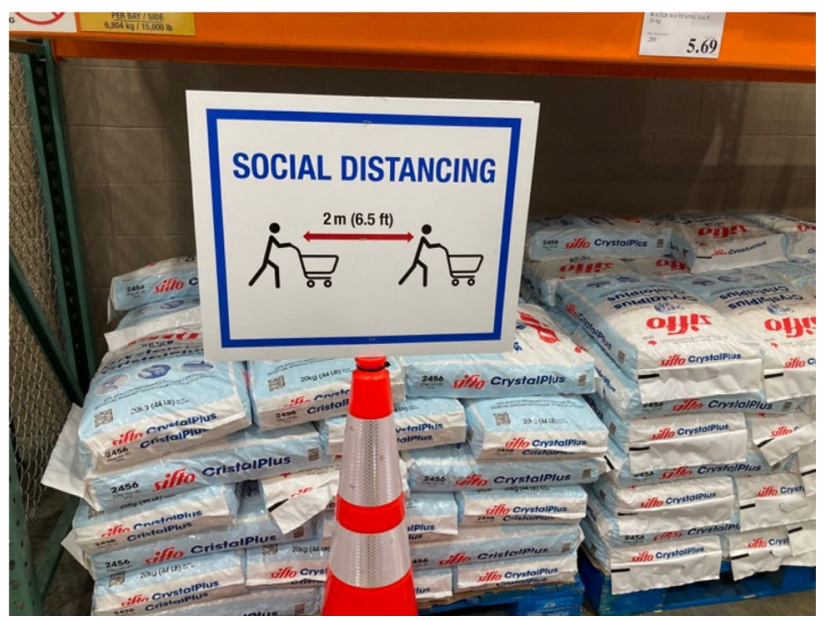


Fig. 23 Costco: $2 \mathrm{~m}(6.5 \mathrm{ft})$

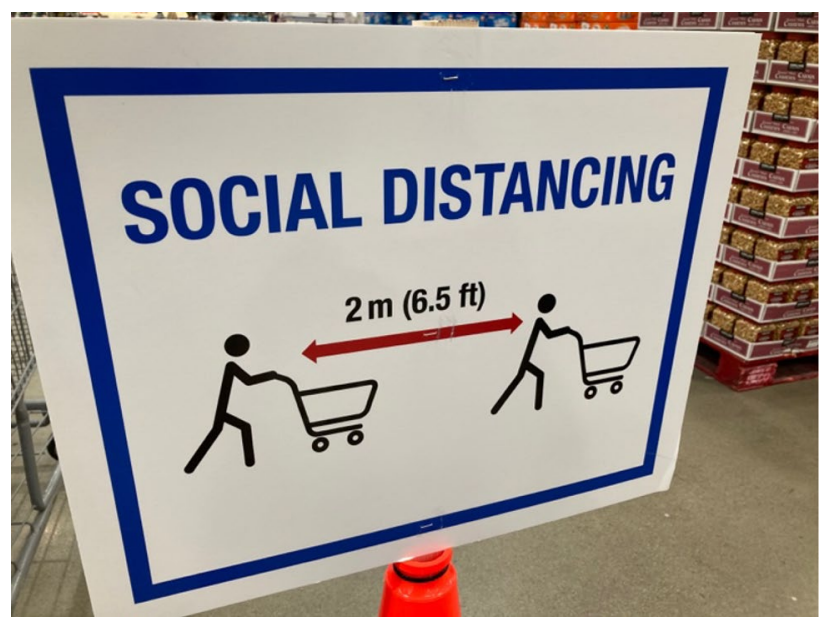

there was one significant difference: the conversion! Costco has a simple sign, really. Presentation of the metric system, which is followed by, what I would call, a somewhat appropriate conversion to the imperial system. Simple and to the point. I get it, $2 \mathrm{~m}$ is not $6.5 \mathrm{ft}$, but given what was out there, I had a front runner when it came to big business. In fact, I was pleased enough with the Costco signage that I did not even bother to think about the notion of whether it would be more appropriate to present " $6.5 \mathrm{ft}$ " as " $61 / 2$ feet" on the sign for the imperial portion. Skipping the food court on the way out, where it seemed like everyone was having hot dogs for dinner that evening, I made a plan to visit what some of the more Canadian big business were doing for social distancing signage, which brings me back to scrolling through the pictures on my wife's phone on the way back to Saskatoon.

Disappointed, for all of us, with some of the signage at Home Depot and Winners, I visited a few big business that are deemed a tad more Canadian. Canadian big business, I thought, might be a bit more like Costco with their signs. As such, I went and visited Mountain Equipment Coop or MEC (Fig. 24), Tim Hortons (Fig. 25), Lululemon (Fig. 26) and Home Hardware (Fig. 27). I should point out, here, that Canadian big business is a term that is meant to be descriptive and not definitive. For example, Tim Hortons, yes, is an integral part of Canada, but its parent organization is

Fig. 24 Mountain Equipment Coop: $2 \mathrm{~m}$ (or 1 grizzly bear)

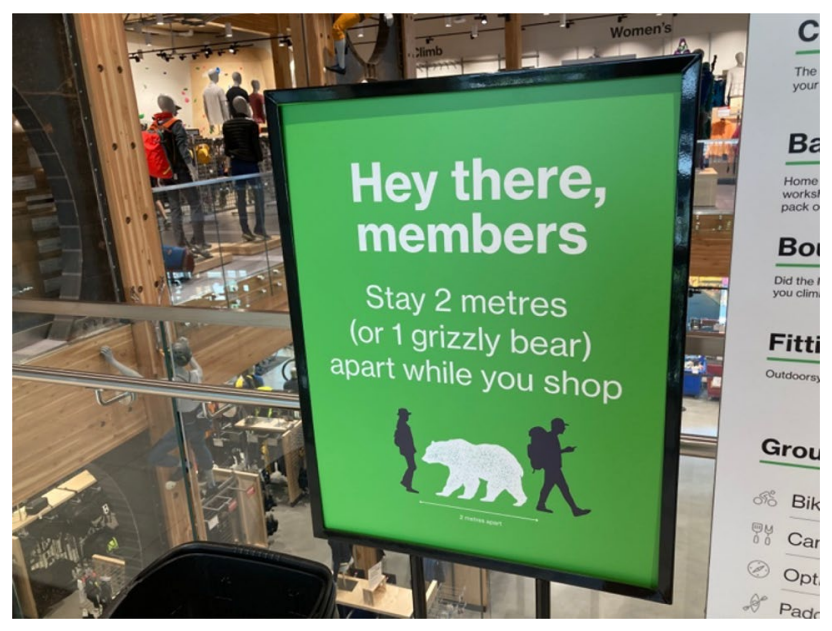


Fig. 25 Tim Horton's: 46

Timbits

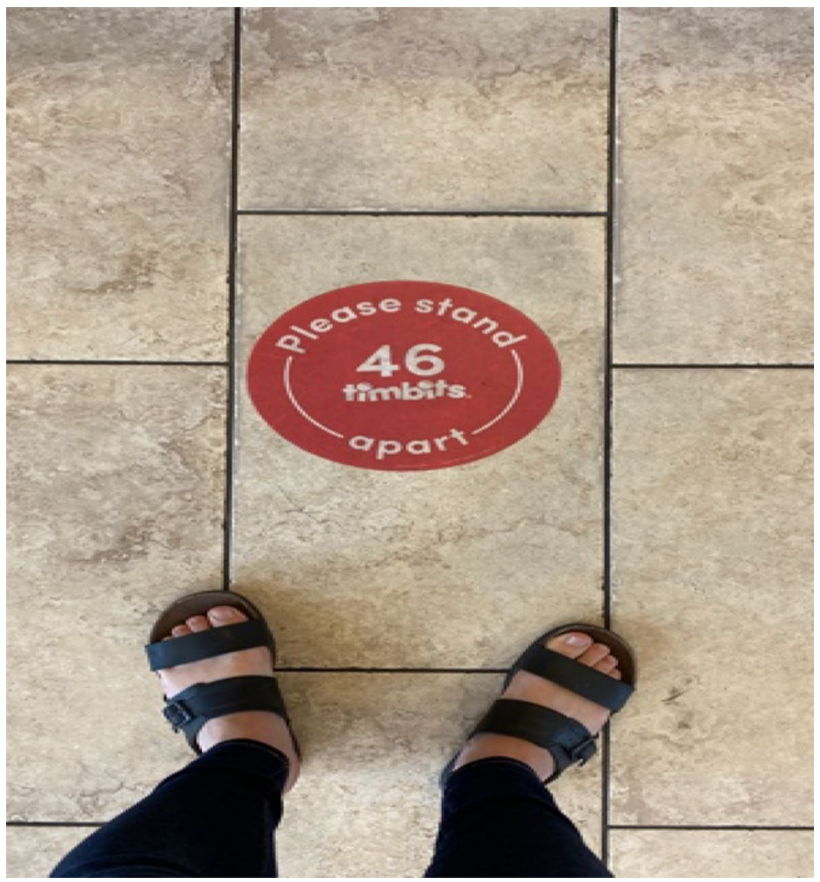

Wendy's, the Columbus, OH, USA, international fast food restaurant behemoth. Similarly, despite its Canadian roots, MEC was recently purchase by an American private investment firm. Nevertheless, these stores qualified as more Canadian, in my eyes.

The sign at Home Hardware is one that $\mathrm{I}$ had seen a million times at this point: metric before imperial and a careless conversion. Also like many other signs, an elaboration asking people to stay " $2 \mathrm{~m}$ apart", which is a nice metric touch. Lululemon was a bit more disappointing. The image of a yoga mat on the floor works well, in my opinion; however, all of Lululemon's yoga mats, those on their website at the time of writing this article, measure $2.13 \mathrm{~m}$ in length, which is different than the $6 \mathrm{ft}$ or $1.8233 \mathrm{~m}$ request from the sign. Not a big difference, mind you. Putting all of the Lululemon sign details together in my mind while staring at that big dot on the floor, that is, no metric system from a Canadian founded company, knowing that a yoga mat does not measure $6 \mathrm{ft}$ or $2 \mathrm{~m}$, knowing that everyone else is saying

Fig. 26 Lululemon: one full yoga mat length $(6 \mathrm{ft})$

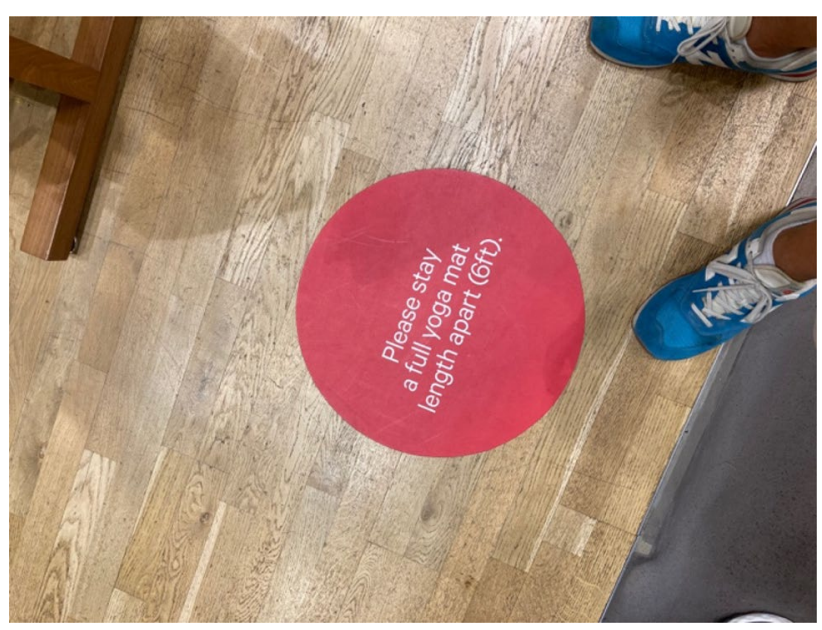


Fig. 27 Home Hardware: 2 $\mathrm{m} \mid 6 \mathrm{ft}$

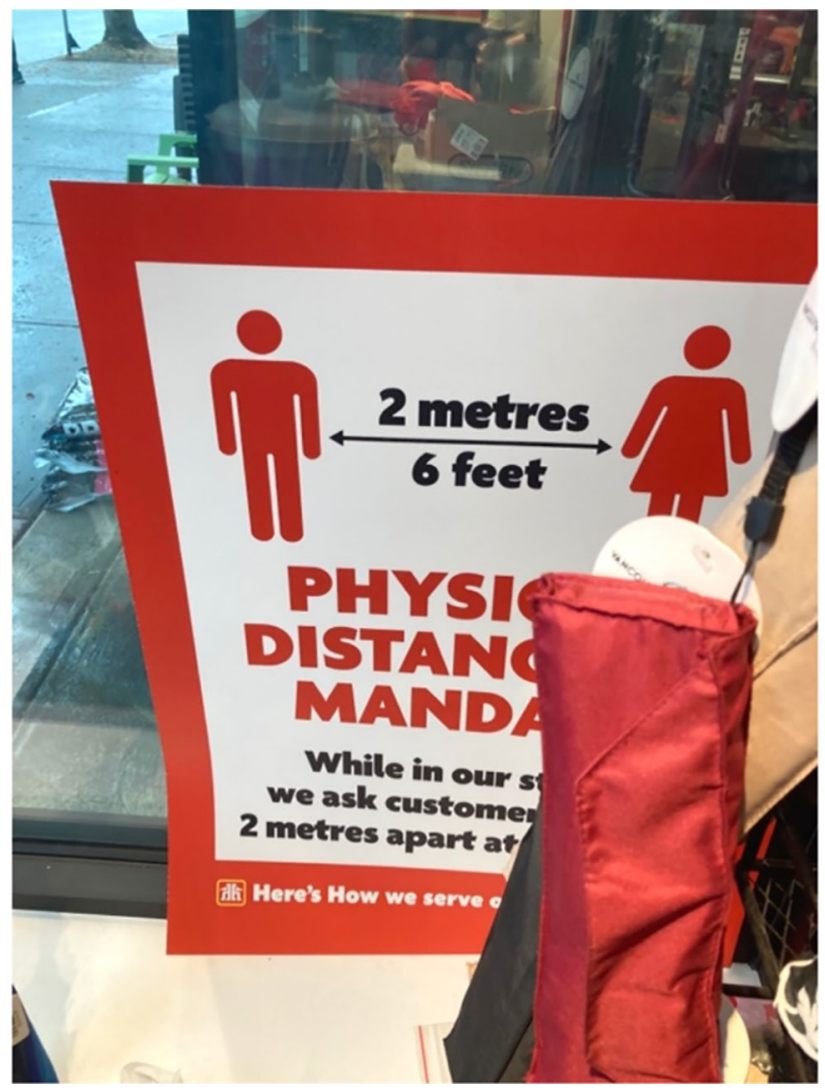

$6 \mathrm{ft}$ is $2 \mathrm{~m}$ or $2 \mathrm{~m}$ is $6 \mathrm{ft}$, I came to two stark realizations. One, I had hit rock bottom in my quest and, two, I could be the only one concerned about careless, cutting conversions of the metric system. As the saying goes, it is not how many times you get knocked down, it is how many times you get back up. I soldiered on to MEC.

MEC, perking up my spirits, avoided the imperial system altogether and, instead, asked people to stay " $2 \mathrm{~m}$ (or 1 grizzly bear apart)". Having seen partial hockey sticks and hiking poles, antler width, orange buckets, shopping carts and arm's lengths as alternative framings for $2 \mathrm{~m}$, the grizzly bear, for me, stood out as an alternative metric. Like the case of the yoga mat, I was skeptical, but not for long. Typing "grizzly bear length" on my iPhone immediately returned " $2 \mathrm{~m}$ " as the top hit. Digging a few links down on my search it turns out that the average total length for a grizzly bear is $6.5 \mathrm{ft}$. Well done, MEC. I imagine little kiddos running around the store, gearing up for getting into nature, learning about wildlife and the metric system. It was time to celebrate with a "Tims", but any notion of a celebration was soon squashed.

There are a few things I like and a few things I do not like about Tim Hortons. The whole Timbits Sports things is super cute, for example. And, for a brief period of time, they were running some very Canadian themed commercials with topics that made more than a few people cry. I would be remiss, here, not to mention the sour cream glazed donut. My god! As for things I do not like, their old coffee cup lids and their new coffee cup lids. I am also not a fan of their social distancing signage. "Please stand 46 Timbits apart", yes, is cute, but that is about it. I get it from a bunch of angles. Timbits are a big part of the brand and the length of 46 Timbits has been tested on TikTok and other social media platforms 
Fig. 28 SoftMoc: 2 METERS

(6 FEET)

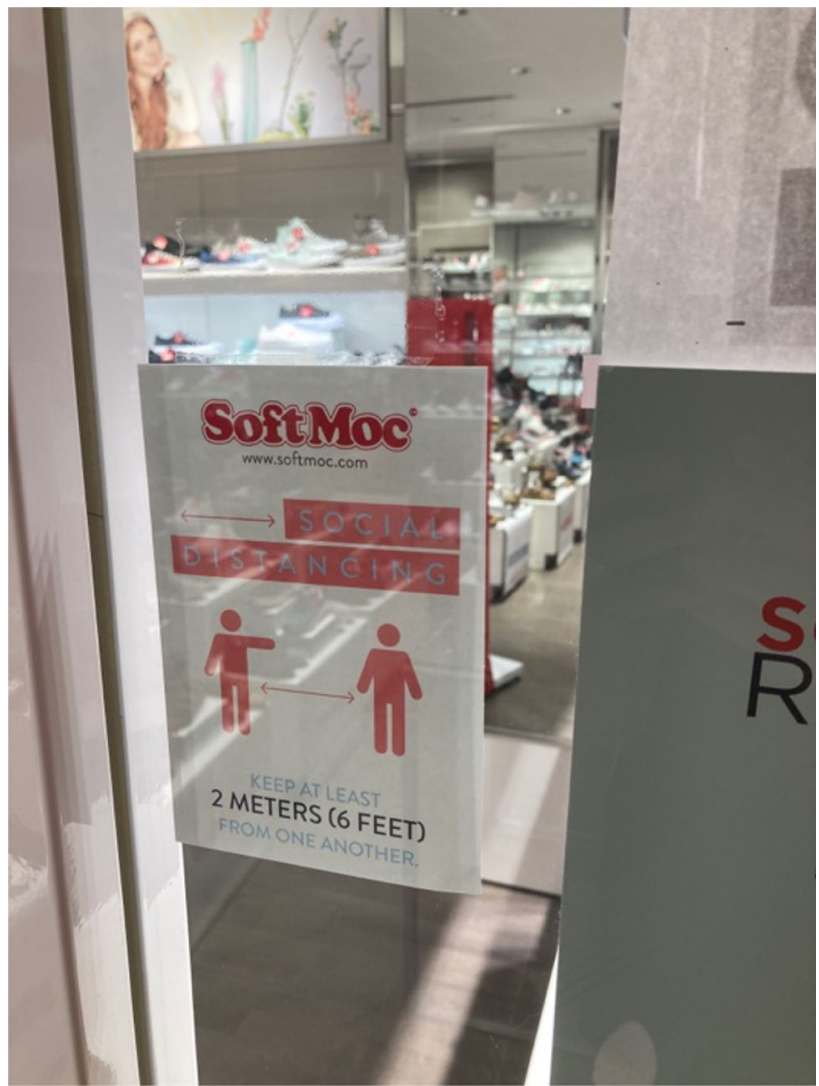

numerous times, to come out close to 6 feet. However, any company self-professing as a cultural fixture of the country of Canada necessitates the use of the metric system on social distancing signage during the COVID-19 global pandemic. Period. With a coffee now in my hands, defeated from my visits to Lululemon and Tim Hortons, it was time to realize that my ideal metric vision was nowhere to be seen. Maybe it was time to wrap up my informal investigation into the poor presentation of the metric system, which I saw everywhere I looked.

Fig. 29 Purdy's Chocolatier:

$2 \mathrm{ml}(6 \mathrm{ft})$

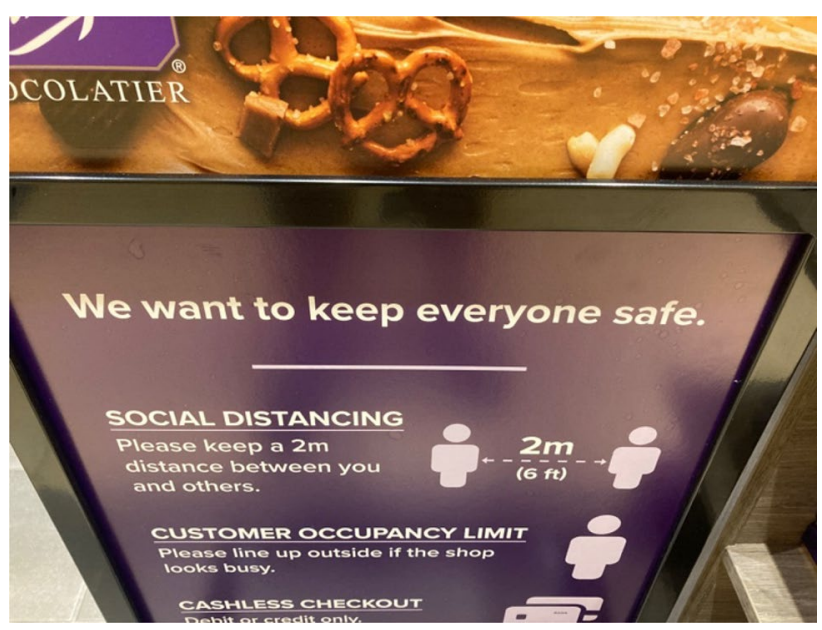


Fig. 30 Mall floor signage: 6 feet

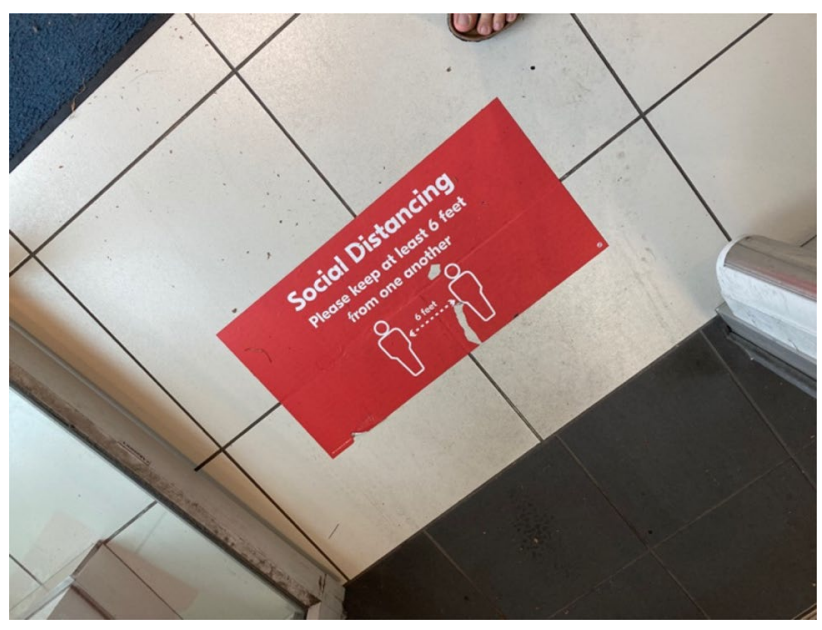

\section{Tempest in a Teapot}

Now months on from first seeing the Chilliwack sign, now with numerous pictures in my pocket, I still could not shake the words of my wife, which just kept ringing in my ears.

As you always do, you are making too big a deal of all this, Egan

As you always do, you are making too big a deal of all this, Egan

As you always do, you are making too big a deal of all this, Egan

Self-doubt had sunk in, unfortunately. My earlier conviction of a causal, corrosive, Canadian indifference to the metric system, which was all around me and other Canadians all the time, only mattered to me and me alone?! What about the lady on the plane? In good conscience, I could no longer proclaim the metric system as one of those big differences. We blew it during COVID-19, Canada.

I imagined, for whatever reason, the lady on the plane had made her way to Canada. And say she went to, of all things, a Canadian mall. Messages of staying " $2 \mathrm{~m}$ (6 feet)" would be found hanging up in SoftMoc (Fig. 28) and Purdy's Chocolatier (Fig. 29). Mall signage, as is the case at Oakridge Mall, would ask her to stay " $2 \mathrm{~m} / 6 \mathrm{ft}$ " apart during her visit, sure. Being European, I imagined her, like me, questioning whether people in Canada knew that $2 \mathrm{~m}$ was not $6 \mathrm{ft}$. I cannot be the only person concerned with this issue. I cannot. I also imagine her questioning the spelling of "METERS" as opposed to "METRES" (Fig. 28).

Fig. 31 More mall floor signage: 6 ,

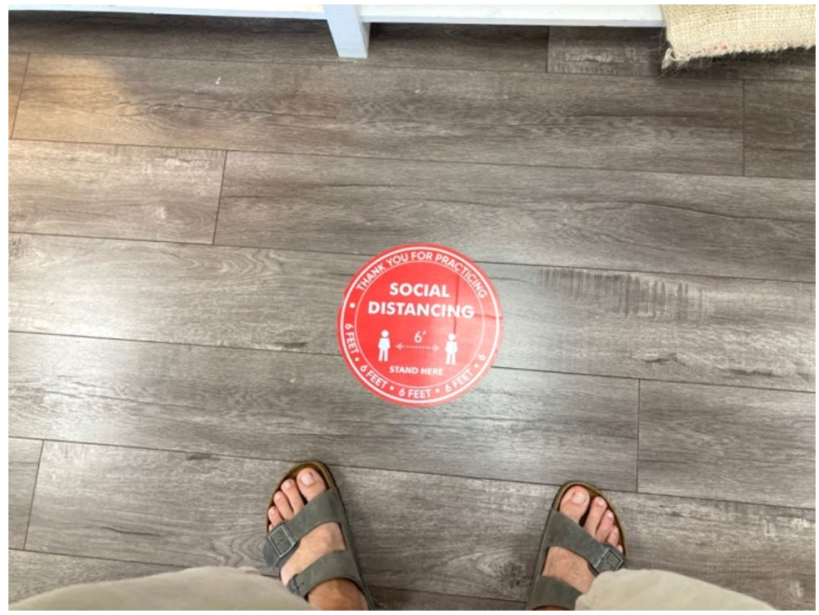


If there is one thing I wished, I wished for the lady on the plane, during her fictitious visit to Canada, while in the mall, to not look down on the floor. Had she looked down at the floor, all she would see is feet. Six feet, in particular (Figs. 30 and 31). "6 feet?! I thought I was in Canada"? I imagine her saying to herself as she waited in line for her purchases. "It must be that Canadians do not know that $2 \mathrm{~m}$ does not equal six feet, wow"! I further imagine her thinking. I then picture two more things.

First, I picture a future world where the COVID-19 global pandemic is over. In this scenario, things have gotten well enough that I am able to fly to attend conferences again. Coincidently, yup, you guessed it, my seatmate and I are reunited for another flight. I know, I know, quite the coincidence, but go with me on this one.

"You will never guess what, I was able to visit your lovely country recently", she begins. She continues, "I remember, last time, when we were talking about major differences between Canada and the USA, you said..." And there I am, attempting to defend something that I am, personally, unable to defend. "Well, it is really hard to truly measure the impact of the USA on Canada", I would say at first. "Our cultures, when you really look at it, are somewhat interwoven", I continue. Maybe a quick call back to CanCon percentages, not on the radio or television, but now on streaming services like Netflix could help my point. I would make sure to talk about the recent success of Schitt's Creek at the 72nd Emmy Awards. Maybe something about Ketchup Chips could help my case. In the end, it does not matter, I know, in my heart, that the metric system was being poorly presented in Canada during this global pandemic and, really, there is nothing I can do about it. No matter how you slice it, this hypothetical scenario is very disheartening. Then, there is the other thing.

Fig. 32 NHLPA: One hockey stick apart

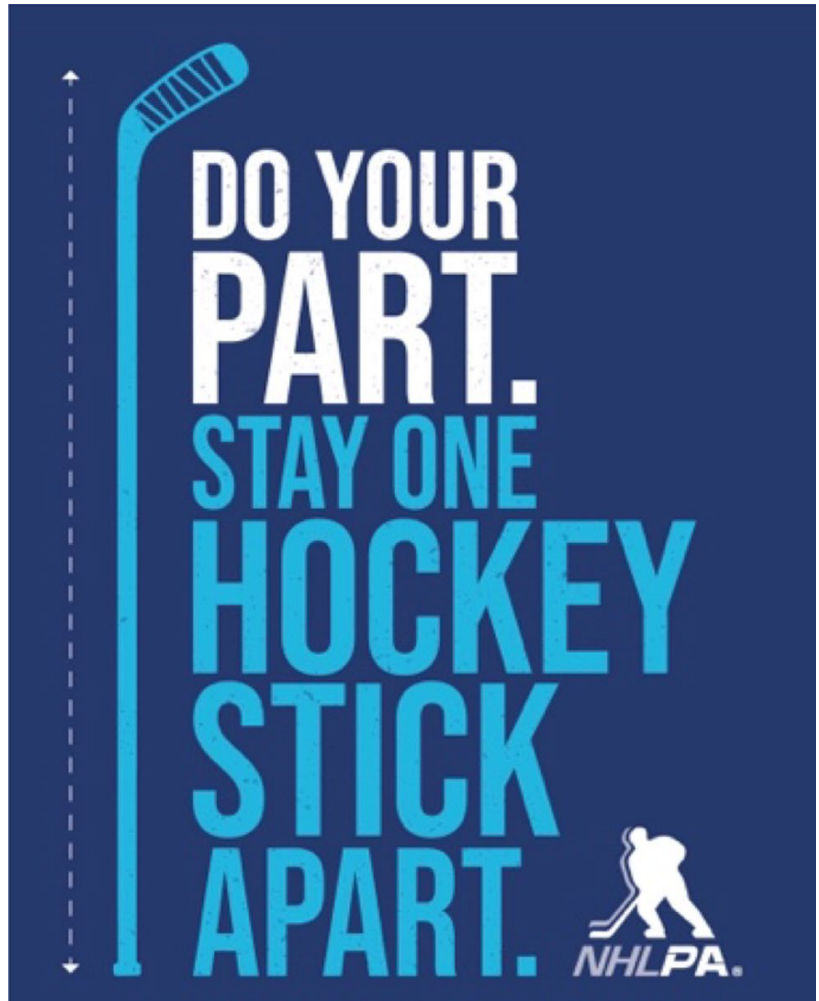

AN IMPORTANT PHYSICAL DISTANCING REMINDER FROM THE NHLPA 


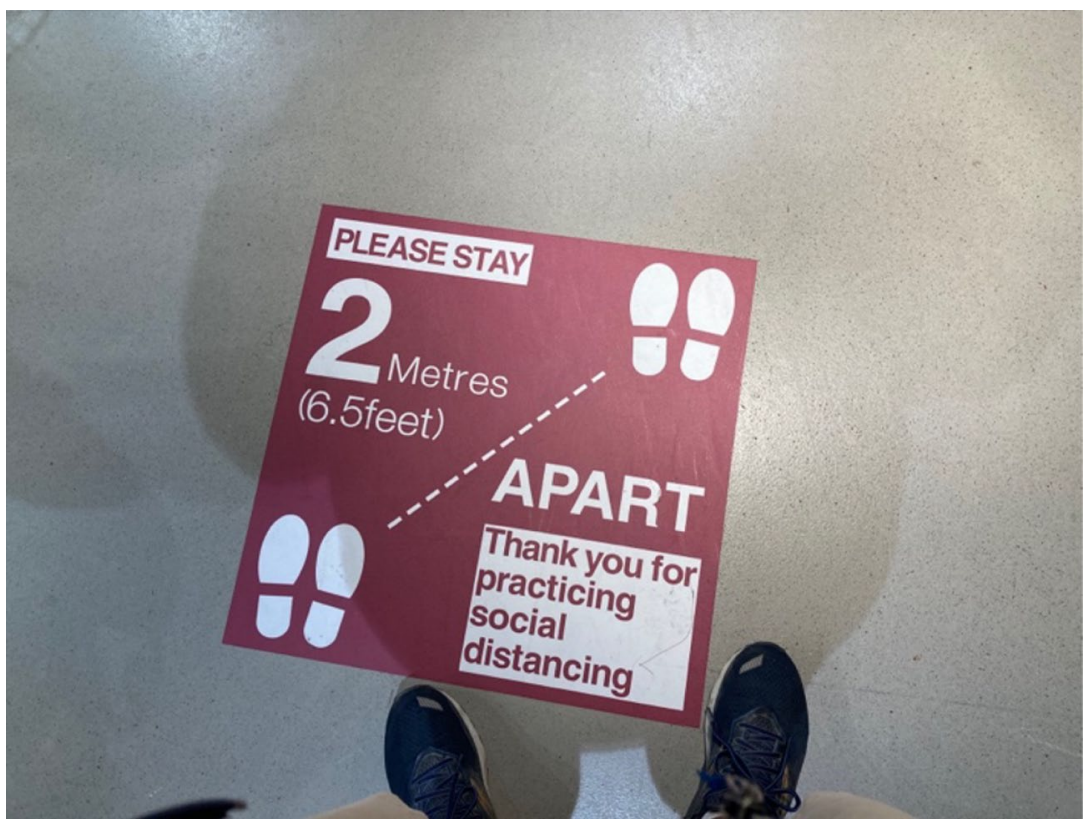

Fig. 33 Fogotten location

The other thing, the last thing I am picturing, yes, is also disheartening, but it is not fictitious. Whether you call it physical distancing or social distancing, whether you go with $2 \mathrm{~m}$ or with $6 \mathrm{ft}$, no matter where I look, no matter how many signs are on the walls and on the floors, people were not and are not adhering to social/physical distancing guidelines. Many, many individuals here in Canada, whether inside or outside, are not staying $2 \mathrm{~m}, 6 \mathrm{ft}, 6.56168 \mathrm{ft}$ or $1.8288 \mathrm{~m}$ apart from each other. In fact, the next time you are out, keep count of how many times you encounter people not even staying the WHO guidelines of $1 \mathrm{~m}$ or $3 \mathrm{ft}$ apart from each other. Be careful, though, because, like me, you will become numb to it all. It is disheartening, in my opinion.

As I read the latest issue of The Hockey News, I flip past a page sponsored by the National Hockey League Players' Association (NHLPA) that asks people to "Do your part. Stay one hockey stick apart" (Fig. 32). My reaction these days, "Good luck, NHLPA!" I see probably the greatest distancing sign I have encountered in quite some time; snap a photo, and I know it is my photo because those are my shoes found in Fig. 33, but I am so numb to things at this point that I forget where I even took the photo. I was really getting worried about myself at this point.

"Wait, all those photos over all those months and you are not taking this one? What is the matter with you? I will take it then". Those are the words of my wife as we are boarding the SeaBus (Fig. 34) to get from downtown Vancouver to North Vancouver on yet another trip to check in on our family during COVID-19.

Another trip means more hikes. More hikes means more social distancing signage (not pictured because I am getting even further defeated as I write this section). On the hike, part of which is an old, wide logging road, you guessed it, all the room in the world. The people that we encounter on said road, you also guessed it, do not move over and are approximately $2 \mathrm{ft}$ away as they breathe 
Fig. 34 Vancouver SeaBus: $2 \mathrm{~m}$ is about the length of...

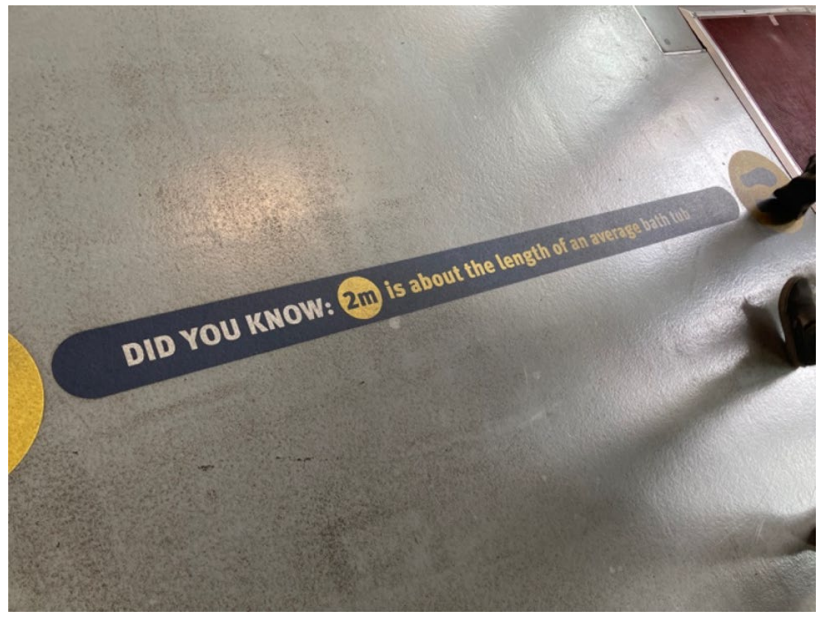

heavily while passing. I know, I know, it is outside. At this point, for me, that is not the point. "Why not just move over a bit"? I think to myself. I also notice that I am starting to internalize everything that happens, which means I am about to leave all this behind.

There is no shortage of different, interesting COVID-19 distancing signage. An eyeglass store of all places, as seen in Fig. 35, for example, puts the imperial system before the metric system, does not bother with conversion and, for further reference, uses a moose. A moose! Lots going on there, but I cannot be bothered. Once I look past the sign into the store, people are on top of each other trying on the same frames. In some instances, strangers are just handing frames to one another while standing inches apart.

Thoroughly defeated I decided, right then, right there, I am done documenting the poor presentation of the metric system here in Canada during the COVID-19 global pandemic. In the past, I have been looking at the signs for specific details regarding conversion, non-standard units of measurement (e.g., a moose), order and more. Now, no matter the sign, all I see is indifference to the metric system. Sure, some signs are better than others. But if people are not adhering to the signage, any details are rendered moot.

Fig. 35 Eyeglass store (Vancouver): 6 feet / $2 \mathrm{~m}$

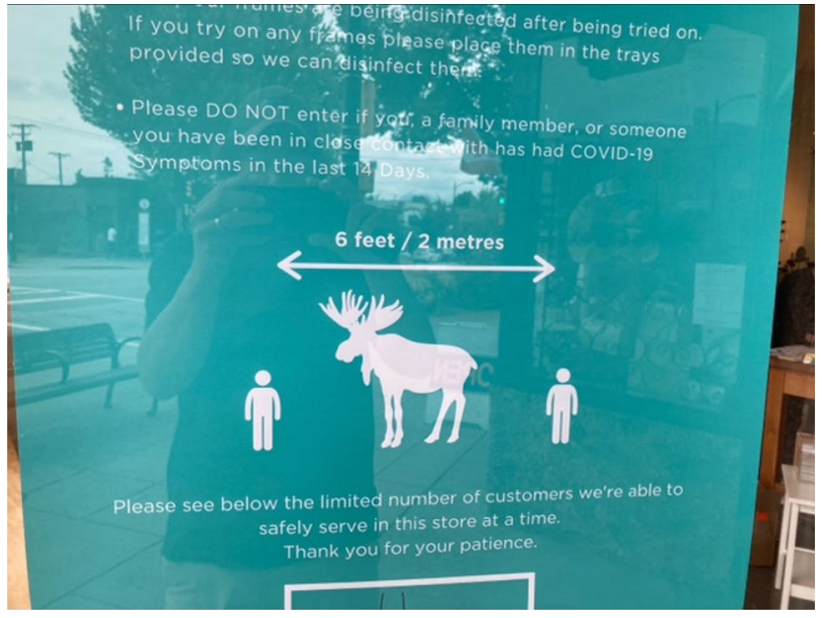


Fig. 36 Canada Place (Vancouver): 17 jugs of maple syrup

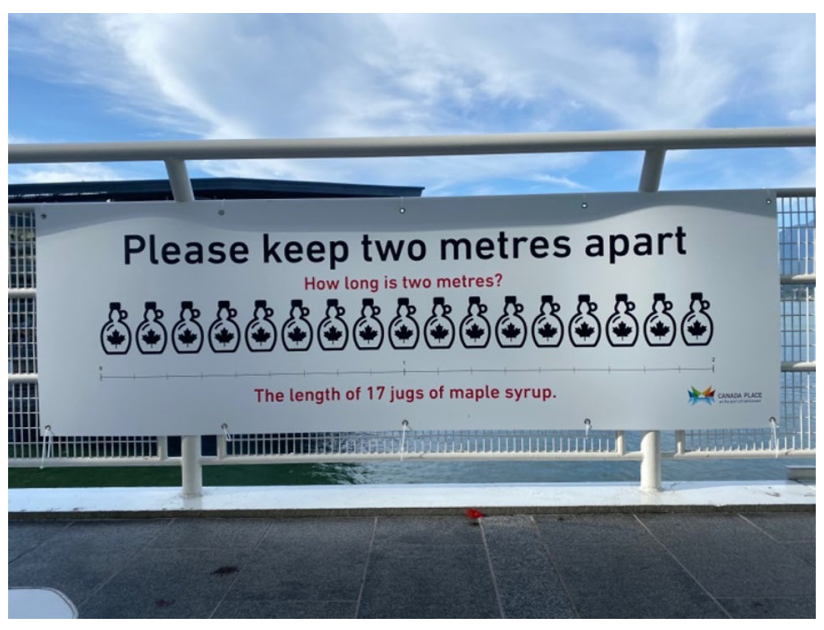

I think we had an opportunity, here in Canada, to delve into the metre as a metric. How far is $2 \mathrm{~m}$ ? Answering with metric conversions, $2 \mathrm{~m}$ is: $2000 \mathrm{~mm}, 200 \mathrm{~cm}, 20 \mathrm{dm}$ and $0.002(2 / 1000) \mathrm{km}$. It is not $6 \mathrm{ft}$. Lest I forget those of you looking to let your metric freak flag fly, I will also accept your (1) meridional, (2) prototype metre bar, (3) wavelength or (4) speed of light definition for the basic unit of length in the International System of Units. It sounds a bit silly, but we did have an opportunity to let people know, at one point in our history, $2 \mathrm{~m}$ was two ten-millionths the distance from the equator to the North Pole along a particular line passing through the city of Paris, France during COVID-19. We did not. Rather, we went down the 17 jugs of maple syrup (Fig. 36) route.

To be clear, I contend that it is not the metre as a metric (as a unit of measurement) that has failed us during COVID-19. It is not the signs that are failing us during COVID-19. After all, it is not what is said, it is what is heard. I think we are all to blame for Canada's COVID-19 conversion kerfuffle; after all, we all let this happen on our watch. For me, personally, it is time to move on from distancing signage. I have way more pressing issues to attend to these days; for example, it has been way too many months since I last flipped my mattress. It is clearly time to start looking for other Canadian mathematics education matters.

\section{Declarations}

Competing interests The author declares no competing interests.

Publisher's Note Springer Nature remains neutral with regard to jurisdictional claims in published maps and institutional affiliations. 